\title{
Hacia una reinterpretación de la historia norteamericana: 126 títulos en bibliotecas mexicanas*
}

\author{
Silvia Núñez García, Ana Rosa Suárez Argüello \\ Ma. Marcela Terrazas y Basante, Guillermo Zermeño Padilla
}

Daniel Cosío Villegas escribía en 1968: "Si ha habido y hay algún país en el mundo que tuvo, tiene y tendría necesidad de estudiar y entender a los Estados Unidos, ese pais es México."

Sin embargo, hasta la fecha, no contamos sino con una historia general de los Estados Unidos escrita por un mexicano: la obra de Benito Pérez Verdia titulada Nociones de Historia de Estados Unidos. ${ }^{2}$ Se trata de un resumen superficial que, quizá en su momento (1944), respondió a un cierto incentivo por dar a conocer la historia de nuestro vecino país del norte. Actualmente en las librerías se consiguen algunos textos de historia general norteamericana, pero lamentablemente se trata de traducciones tardías. A nuestras bibliotecas sólo llega un número limitado de la inmensa producción historiográfica norteamericana.

Por otro lado, no podemos dejar de mencionar que en nuestro país se han realizado investigaciones sobre temas específicos acerca de los Estados Unidos de corte sociológico, político o económico, sin olvidar por ello los escasos estudios propiamente históricos.

Quizá no se ha escrito en México una historia general de los Estados Unidos debido a varias causas: falta de interés por el pasado de esta nación, poca simpatía por su cultura, rencor por los territorios perdidos, diferencias ideológicas... Asimismo, cabe señalar que al parecer no existe en nuestro país una conciencia general de la necesidad de estudiar el proceso histórico norteamericano. Se puede observar, sí, un conocimiento surgido de prejuicios originados en nuestro incómodo pasado común, que tienen que ver más bien con estereotipos que con una apreciación histórica objetiva, condición sine qua non para el establecimiento de unas relaciones más justas entre los dos países.

En este sentido, creemos que la afirmación de Cosio Villegas en 1968 no sólo no ha perdido vigencia sino que la necesidad de "estudiar y entender" a los Estados Unidos se ha hecho cada dia más urgente. Nadie puede negar que hoy, como entonces, el futuro de México se encuentra estrechamente ligado al norteamericano.

Conscientes de que no es la primera vez que se llama la atención sobre la necesidad de llenar este vacio,${ }^{3}$ nos proponemos con esta revisión

\footnotetext{
* Colaboraron en la investigación Ma. Eugenia de Lara Rangel y Angela Moyano Pa. hissa. Agradecemos el apoyo técnico de Ma. Luisa Ruiz Sandoval y de Carlos Zolezzi Feher.

1 Daniel Cosío Villegas, "De la necesidad de estudiar a Estados Unidos", en Anglia. Anuario/Estudios angloamericanos, México, Universidad Nacional Autónoma de México, 1968 , vol. 1, p. 9-17, p. 10.

2 Véase bibliografia comentada, núm. 47.

${ }^{3}$ María Cristina Montaño, "La comprensión de la historia de los Estados Unidos como un elemento esencial para la liberación nacional", en Iztapalapa. Revista de ciencias sociales y humanidades, México, Universidad Autónoma Metropolitana, 1981, Año 2, núm. 4, p. 222-242.
} 
bibliográfica aportar un primer análisis de los textos de historia general de los Estados Unidos asequibles en las principales bibliotecas de la ciudad de México. Tenemos la idea de que esto, además de facilitar un acercamiento al proceso dé conformación de la sociedad norteamericana, puede resultaŕ de gran utilidad ya que cada una de las obras estudiadas - que como ya dijimos constituyen sólo una muestra de la abundante producción bibliográfica de los Estados Unidos acerca de su historia - ha quedado enmarcada en una de las corrientes historiográficas más representativas. Y, por supuesto, toda obra de historia es a la vez componente y expresión de su época.

Entre los historiadores norteamericanos existe, en general, el acuerdo de dividir su producción histórica profesional en cuatro grandes corrientes: ${ }^{4}$ la nacionalista o patriótica (1870-1910 aproximadamente), la progresista (1910-1940 aproximadamente), la del consenso o neoconservadora (1940-1960 aproximadamente) y la revisionista o de la "multihistoria" (1960...). Debe anotarse que este criterio de clasificación no es rígido, pues existen obras que no se ajustan a la tendencia historiográfica predominante en el momento de su primera edición. En estos casos, la excepción sólo confirmará la regla.

A continuación presentamos una caracterización general de las cuatro corrientes arriba señaladas:

\section{La corriente patribtica o nacionalista}

La historiografía norteamericana empieza a escribirse de manera profesional durante el último tercio del siglo XIX. Surge como heredera de una tradición de historiadores "aficionados", dedicados fundamentalmente a actividades políticas. Tal es el caso, entre otros, de Thomas Jefferson y Jeremy Belknap, quienes pretenden justificar el establecimiento de la nueva nación con la exaltación de valores como el del "excepcionalismo", frente a la imagen de una Europa corrupta y decadente. En el contexto nacionalista de su época, estos puntos de vista no dejan de ser chauvinistas.

Con George Bancroft, ${ }^{5}$ la concepción nacionalista de la historia toma forma coherente y definitiva y llegará propiamente a consolidarse con la primera generación de historiadores profesionales. Estos fundarán la American Historical Association en 1884 y comenzarán a difundir sus trabajos en órganos especializados, como la American Historical Review, cuyo primer número aparece en 1895.

Tres temas recurrentes se encuentran en sus escritos, orientados a instruir y formar la conciencia nacional de un pueblo de inmigrantes en constante expansión territorial: la idea del progreso, la de la libertad y la del "destino manifiesto". Esta trilogia puede verse como un resabio secularizado de la tradición puritana ${ }^{6}$

Este grupo de académicos de la historia, resultado del desarrollo de la educación superior que tiene lugar en la etapa de la Reconstrucción

\footnotetext{
4 Véase Gerald Grob y George Athan Billias, en Intexpretations of American History. Patterns and Perspectives. Fourth Edition, Nueva York, The Free Press, 1982, 2 vols., vol. 1, p. 2 y ss.

Véase bibliografía comentada, núm. 1 .

- Aunque Grob y Billias hablan en este sentido de los historiadores patricios - los "aficionados" dedicados principalmente a actividades politicas-(ibidem, vol. 1, p. 3), la idea es válida para los historiadores nacionalistas.
} 
(1865-1973), enfoca sus trabajos a reforzar el espíritu de unidad quebrantado por la guerra civil o de secesión si bien lo proyecta desde la perspectiva de los vencedores. Se impone igualmente la tarea de apoyar el proceso de "americanización" de los miles de recién llegados, fuerza latente de fragmentación social que podia amenazar la consolidación del sistema industrial capitalista.

Conviene mencionar que esta nueva clase de intelectuales provienen de estratos sociales medios y de diversas regiones geográficas, a diferencia de sus antecesores, miembros en su mayoria de la elite del noreste. Estas características quedan representadas con claridad en la figura de Frederick Jackson Turner, cuyos trabajos marcan la transición de la historiografía nacionalista a la progresista.

\section{La corriente progresista}

En La Frontera en la historia americana, ${ }^{7}$ Turner trata de fijar los origenes de la indentidad nacional en el hombre de la frontera y de explicar el desarrollo histórico de los Estados Unidos a partir del conflicto entre sus regiones. Su concepto de conflicto será retomado por la corriente progresista que -consciente de la importancia de la historia económica - destacará los antagonismos no sólo regionales, sino entre clases sociales, propietarios y desposeídos, privilegiados y no privilegiados, conservadores y demócratas. Sus autores los manejarán como una constante de la sociedad norteamericana.

La nueva corriente, influida por el movimiento progresista de los primeros años del siglo XX y por la decepción que sucede al fin de la primera guerra mundial, surge alrededor de 1910. Nace en medio del predominio del capital financiero y de los monopolios, fuerzas económicas que amenazan seriamente a la democracia liberal -la del laissezfaire... - del capitalismo industrial. Esta escuela será también testigo de la conversión de los Estados Unidos en una potencia mundial.

Los historiadores del conflicto - como también se les ha llamadopresentan la discontinuidad de una historia interrumpida por momentos críticos. Así, la independencia es vista no como una simple guerra para obtener la separación de Inglaterra, sino como una revolución, ${ }^{8} \mathrm{y}$ a la guerra civil la llaman la "segunda revolución americana". ${ }^{9}$ La sociedad es concebida como una entidad dinámica y abierta: su desarrollo -evolutivo, de progreso- obedece a fuerzas sociales y económicas surgidas de la interacción entre el individuo y el medio.

Los historiadores progresistas consideran que para entender el proceso social hace falta conocer y comprender críticamente el pasado. Sólo asi podrán hacerse los cambios necesarios para un progreso ulterior. En este sentido, la historia desempeña el papel de herramienta para el cambio. Al mismo tiempo buscan la "neutralidad moral" y la "objetividad científica". Opinan que la historia, aunada a las demás ciencias sociales, puede explicar la realidad al esclarecer la interacción entre las fuerzas económicas, políticas, sociales, tecnológicas, sicológicas, etcétera. De esta forma se amplia el campo de la historia que se hallaba reducido al estrecho ámbito de lo político, lo militar y lo diplomático.

7 Véase bibliografia comentada, núm. 8.

8 John Higham, "The Cult of the 'American Consensus'. Homogenizing Our History", en Commentary, Nueva York, The American Jewish Committee, 1959, vol. 27, p. 93-100, p. 95 .

9 Véase bibliografía comentada, núm. 19 y 24. 
La historiografía del conflicto comienza a perder fuerza a partir de la década de los treintas. El surgimiento del fascismo y del nazismo hace que muchos intelectuales norteamericanos adopten una postura escéptica acerca del progreso. ${ }^{10}$ Consideran que, con esta perspectiva, la historiografía no ha preparado al pueblo de los Estados Unidos para hacer frente a la amenaza totalitaria."

\section{La corriente del consenso o neoconservadora}

Después de la segunda guerra mundial, el colapso europeo, los horrores de la contienda y de los campos de concentración activan el cambio de dirección de la historiografía norteamericana que muestra "una disposición a buscar una vez más la promesa del futuro sobre bases nativas, una resurrección del viejo sentimiento de que los Estados Unidos son mejores y diferentes". ${ }^{12}$

La guerra fría propicia "un cierre de filas". ${ }^{13}$ Ante la "amenaza" comunista, ${ }^{14}$ temerosa tanto de la subversión interna como de que la Unión Soviética desencadene una revolución mundial, la historiografía adquiere un carácter marcadamente consensual. Describe una nación unida y estable, una gran comunidad, cuyos habitantes han compartido siempre los principios democráticos -el de que todos los hombres tienen un derecho inalienable a la propiedad privada y a la libertad, por ejemplo-, son poseedores, en fin, de una "experiencia" común. ${ }^{15}$

Los autores del consenso defienden la tesis de la continuidad histórica. Piensan que las viejas y estables instituciones norteamericanas, los principios culturales comunes y algunos rasgos y tradiciones del carácter nacional han persistido a lo largo de su historia. Disminuyen la importancia de las crisis. La independencia de los Estados Unidos no es vista como una revolución, sino como una guerra moderada, limitada a la lucha por la separación de Inglaterra y por los valores democráticos heredados de sus antepasados. La guerra de secesión, más difícil de manejar desde la perspectiva del consenso, pierde relevancia como tema de estudio. ${ }^{16}$

Estos historiadores reducen los conflictos de que hablaban los progresistas a simples ajustes a los cambios institucionales, a crisis propias de la modernidad ${ }^{17} \mathrm{o}$ a actos de personalidades egocéntricas, poco idealistas o sicológicamente perturbadas, más que a fallas del sistema. ${ }^{18} \mathrm{De}$ esta manera solucionan las contradicciones dentro de la sociedad norteamericana, aunque al mismo tiempo quedan incapacitados para tratar de problemas como la efervescencia social o la violencia. ${ }^{19}$

Complacidos por la sociedad en la que viven, convencidos de su excelencia dentro del contexto mundial, indudablemente influidos por el

10 Véase Robert Allen Skotheim, American intellectual histories and historians, Princeton, Princeton University Press, 1966.

11 Véase bibliografía comentada, núm, 30-32, 34-36.

12 Richard Hofstadter, Los historiadores progresistas: Turner, Beard, Parrington, Buenos Aires, Paidós, 1968, p. 400.

${ }_{13}$ Idem.

14 Véase bibliografia comentada, núm. 46.

is Véase bibliografia comentada, núm. 93, 96, 99 y 103.

16 Higham, op. cit., p. 95.

17 Véase bibliografía comentada, núm. 50.

18 Mary Norton et al., A people \& a nation. A history of the United States, Boston, Hougton Mifflin, 1982, 984, p., ils., maps., fots., p. 862.

19 Higham, op. cit., p. 100. 
florecimiento económico sin precedentes de la posguerra, los neoconservadores - llamados así porque, en cierta forma, dan nueva vigencia a las ideas de la escuela patriótica - sostienen la tesis del "excepcionalismo" norteamericano: su país es "gigantesco y único". ${ }^{20} \mathrm{Su}$ historia resume "la historia de la especie" 21 y su misión, a decir de Louis Hartz, es influir sobre la humanidad, "no por las armas o el dinero, sino por la fuerza del ejemplo". ${ }^{22}$ Aceptan los cambios, "las innumerables, imperceptibles revoluciones", ${ }^{23}$ siempre y cuando éstas sean guiadas por la experiencia y se ajusten a los moldes sociales existentes. ${ }^{24}$ Moldes que, en buena medida, favorecen el desarrollo de una burguesía para la cual el sueño norteamericano es prácticamente una realidad.

Es conveniente precisar que hay algunos autores que, pese a que publican durante la etapa del consenso, no pueden clasificarse como historiadores de dicha corriente. Las particularidades de sus obras rebasan los patrones dominantes de la historiografía neoconservadora y permiten advertir el tránsito hacia la corriente revisionista. La obra de Leo Huberman, traducida en México en la década de los setenta, constituye una buena muestra de historia crítico-narrativa desde una perspectiva marxista. ${ }^{25}$ Otro autor, Hendrick W. Van Loon, traducido en Buenos Aires en 1944, es un ejemplo de la "antihistoria": no sólo no cae en el triunfalismo característico del consenso, sino que lo satiriza. ${ }^{26}$ El trabajo del historiador inglés Frank Thistlethwaite afirma que los Estados Unidos son, en realidad, el "gran experimento" europeo en tierras americanas y no ocultan una mirada escéptica hacia su futuro. ${ }^{27}$ Finalmente, el reconocido historiador Richard Hofstadter representa el eslabón crítico más elaborado del paso de la tradición progresista al revisionismo, sin caer en el anticomunismo que priva en casi todos los autores del cosenso. Forma parte de los progresistas, mas se distancia de éstos y logra mantener una posición independiente frente a las líneas neoconservadoras o marxistas ortodoxas. ${ }^{28}$

\section{La corriente revisionista o de la "multihistoria"}

El enfoque neoconservador continúa, en buena medida, hasta la fecha. Sin embargo, a partir de la década que se inicia en 1960, las tesis de la continuidad y del consenso han sido puestas en tela de juicio por algunas de las tendencias que forman parte de la que se ha llamado corriente revisionista o de la "multihistoria".

Es difícil señalar con precisión el momento en que se inicia el cambio hacia la nueva corriente. No obstante, existen ciertos indicadores que nos permiten registrarlo. Según algunos autores, como Michel Frisch, la obra de Stephan Thernstrom, Poverty and progress. Social mobility in a 19 th century city ${ }^{29}$ es la que marca la transición de la historia

20 Véase bibliografía comentada, núm. 66.

21 Véase bibliografía comentada, núm. 43.

22 Hofstadter, op. cit., p. 406.

23 Véase bibliografia comentada, núm. 95.

24 Jay A. Sigler, ed., La Tradición Conservadora en el pensamiento de los Estados Uni-

dos, México, Editores Asociados, 1972. (Actualidad politicosocial), p. 23.

25 Véase bibliografía comentada, núm. 32.

26 Véase bibliografía comentada, núm. 30.

${ }^{27}$ Véase bibliografía comentada, núm. 33.

28 Véase bibliografía comentada, núm. $31,34,35$ y 36.

29 Cambridge, 1964. 
literario-narrativa a la cuantitativo-explicativa que caracterizará al revisionismo. ${ }^{30}$ La nueva manera de abordar la historia retoma y da forma a la disputa en torno al carácter de las ciencias sociales, entablada por los historiadores progresistas en la época de la entreguerra. Vale recordar que, ya en la posguerra, la historia se abrió finalmente a la influencia de los métodos y enfoques utilizados por otras ciencias tales como la economía, la sociología, la antropología, etcétera.

Además de la innovación técnico-metodológica que tiene lugar dentro del mundo académico, la obra de Thernstrom deja ver también otras novedades, producto del cúmulo de hechos sociales, políticos, económicos y militares que llegan con la década de los sesenta. En estos años se desencadena una serie de acontecimientos en el seno de la sociedad norteamericana que van desde las luchas de los negros por sus derechos civiles hasta los movimientos de protesta estudiantiles de corte antiautoritario y antibélico, como la oposición a la guerra de Vietnam que llegó a generalizarse. Aunado a lo anterior, la lucha de las mujeres, la de las minorías étnicas, la violencia urbana, etc., evidencia que la unidad sostenida por los historiadores del consenso resultaba un mito. La depresión económica de esta época ayuda a poner en entredicho la supuesta movilidad social norteamericana, las virtudes del cambio tecnológico y la pregonada distribución igualitaria de los beneficios del crecimiento económico.

Ante tales condiciones cabe mencionar que durante los primeros años del desarrollo de esta compleja corriente, una de las preocupaciones centrales giró en torno a "la nueva historia urbana". ${ }^{31}$ Asumió después diversas formas temáticas, metodológicas e ideológicopolíticas que se expresaron en la "nueva historia social", la "nueva historia económica", la "nueva historia política", la "nueva izquierda", entre otras. El común denominador de esta "multihistoria" ha sido el afán de transformar la historia en una ciencia nomológica. Ha manifestado también una inquietud preferente hacia los grupos olvidados por la historiografia tradicional: los negros, las mujeres, los indios, las minorías étnicas, los obreros, los campesinos. Mencionados en alguna medida por las historias anteriores, la novedad se da por la perspectiva que el historiador Jesse Lemish denominó en 1967 como la historia "vista desde abajo".32

Después de las anteriores consideraciones de carácter historiográfico, hemos de señalar:

Que la intención de este trabajo no fue la de agotar la totalidad de las historias generales de los Estados Unidos existentes en las principales bibliotecas de la ciudad de México. Se procuró incluir aquéllas que abarcasen todas las etapas clave de la historia norteamericana aunque igualmente se consideró importante introducir, en forma excepcional, algunos libros que cubren periodos más específicos, dada la relevancia de sus autores y el momento en que fueron escritos. Han quedado excluidos, por ejemplo, textos de educación elemental, antologías docu-

30 Michel Frisch, "Tendenzen der Neueren amerikanischen Sozialgeschichte. Die Grenzen der Annäherung", en George G. Iggers, Neue Geschichtswissenschaft vom Historismus zur historischen Sozialwissenschaft, Munich, Deutscher Taschenbuch Verlag, 1978 , p. 228.

31 Idem.

${ }^{32}$ Jesse Lemisch, "The American Revolution Seen from the Bottom Up", en Barton J. Bernstein, ed., Towards a New Past: Dissenting Essays in American History, Nueva York, Pantheon Books, 1968. 
mentales, tratados historiográficos y estudios monográficos, puesto que éstos merecen un tratamiento distinto. Se consideraron, en cambio, las historias generales escritas en o traducidas al español.

En cuanto a la organización del material, primero registramos los titulos encontrados en las bibliotecas Nacional (BNAL), Central (UNAM), de la Facultad de Filosofia y Letras (FLunAM), de El Colegio de México (COLMEX), de la Universidad Iberoamericana (UIA), Benjamín Franklin (BBF) y del Instituto de Investigaciones Dr. José María Luis Mora (BIM). Elaboramos después una nota sobre cada texto, que proporciona tanto su ubicación (con las siglas señaladas) y clasificación bibliotecaria como una idea rápida y certera de su contenido.

Uno de los problemas centrales que tuvimos que enfrentar fue el de la presentación del material. Llegamos a la conclusión de que la mejor manera de hacerlo era la de agrupar los libros en cuatro apartados, de acuerdo al año de edición original de cada uno y al criterio señalado anteriormente de periodización historiográfica. Creimos conveniente incluir las obras de autores no norteamericanos (18, el $14.28 \%$ del total considerado), europeos en su mayoría, dentro de la clasificación anterior, sin que ello signifique que todos pertenezcan, sensu stricto, a las corrientes mencionadas. Habrá el caso de algunos historiadores - particularmente ingleses, franceses o españoles - que mantengan una posición más crítica, permeada por la peculiar perspectiva nacional desde la que escriben. No se trata, por cierto, de dos de los tres latinoamericanos que han publicado una historia general de los Estados Unidos, cuya noción es afín a la corriente del consenso. ${ }^{33}$

Realizado el trabajo anterior, observamos que del total de obras revisadas $126(100 \%)$ en las bibliotecas arriba citạdas, se localizan 72 (57.14\%) en inglés, $2(1.59 \%)$ en francés y $52(41.27 \%)$ en español. De estas últimas, es interesante señalar que sólo cuatro han sido escritas originalmente por autores hispanoamericanos (un español, un mexicano, un chileno y un colombiano), mientras que el resto son textos traducidos en su mayor parte del inglés. En el caso de las obras en francés, la mayoría son traducciones hechas en España.

De acuerdo a los criterios de organización señalados (año de edición original-corriente historiográfica), se puede destacar la preeminencia de la tendencia del "consenso". Sólo a ésta le corresponden 69 títulos, equivalentes a un $54.76 \%$ del total. Durante este periodo, que coincide con un boom historiográfico en los Estados Unidos durante la guerra fría, aparece la mayoría de las obras escritas en o traducidas al español ( 31 de un total de 52, esto es el 60\%) e incluso editadas en México $(14$, el $27 \%)$.

Creemos que este predominio de obras neoconservadoras - tanto en inglés como en español - en las bibliotecas de la ciudad de México contribuye, por medio de los lectores que tienen acceso a ellas, a divulgar la visión de una sociedad plácida, estable, sin conflictos, de una gran comunidad cuyos habitantes comparten ciertos ideales democráticos y están dispuestos a llevarlos a toda la humanidad. Colabora también a conformar un modelo de vida que no sólo es diferente al nuestro, sino que lleva, de manera muy efectiva, a la pérdida de nuestra identidad nacional. Esto, junto con el impacto causado por los medios de comunicación masiva, hace que cada vez sea más importante la tarea de formar, entre el público mexicano, una visión de los Estados Unidos más

33 Véase bibliografia comentada, núm. 40 y 47. 
apegada a los hechos. A ello pueden contribuir, aunque no de manera definitiva, los historiadores revisionistas.

En cuanto a la historiografía nacionalista, su presencia - a nivel de historias generales - es escasa en las bibliotecas visitadas (sólo 7 obras en un total de 126-5.56\%). Casi todas ellas, tanto en inglés como en español, se han publicado en los Estados Unidos. Por lo que toca a la etapa de la historiografia progresista (22 textos $-17.45 \%$ ), puede afirmarse que es entonces cuando comienza a manifestarse en los países de habla hispana un cierto interés por la difusión de la historia norteamericana. Pese a ello, dos de los autores progresistas más relevantes fueron traducidos con algún retraso, durante la década de los años cuarenta, en el periodo del consenso. La versión en español de la obra magna de Charles A. Beard, escrita en cuatro tomos, Historia de la civilización de los Estados de Norteamérica desde sus origenes hasta el presente, fue hecha en Argentina por Rubén Dario hijo, ${ }^{34}$ y la edición mexicana del libro de Harold U. Faulkner, Vida del Pueblo Norteamericano, estuvo a cargo de Daniel Cosio Villegas. ${ }^{35}$

Por último es interesante observar que la corriente revisionista es la que ocupa el tercer lugar ( 21 obras $-16.67 \%$ ) en el total de textos consultados. Dentro de ella sólo tres tienen un enfoque radical que se inserta en la línea de la llamada "nueva izquierda" o posición marxista-revisionista; los de Wasserman, ${ }^{36} \mathrm{Kolko}^{37}$ y Zinn. ${ }^{38} \mathrm{El}$ resto muestra más bien preocupaciones de indole neoprogresistas o metodológicas (trabajos interdisciplinarios, historia comparada, nuevos enfoques temáticos,

\begin{tabular}{|c|c|c|c|c|c|}
\hline $\begin{array}{l}\text { Corriente } \\
\text { idioma }\end{array}$ & inglés & francés & español & & totales \\
\hline $\begin{array}{l}(1870-1910) \\
\text { Nacionalista }\end{array}$ & 3 & & $\begin{array}{ll}\text { E.U. } & 2 \\
\text { España } & 1 \\
\text { México } & 1\end{array}$ & 4 & $\begin{array}{c}7 \\
(5.56 \%)\end{array}$ \\
\hline $\begin{array}{l}(1910-1940) \\
\text { Progresista }\end{array}$ & 12 & 1 & $\begin{array}{ll}\text { México } & 3 \\
\text { Argentina } & 5 \\
\text { España } & 1 \\
\end{array}$ & 9 & $\begin{array}{c}22 \\
(17.45 \%)\end{array}$ \\
\hline $\begin{array}{l}(1940-1960) \\
\text { Disonantes }\end{array}$ & 3 & & $\begin{array}{ll}\text { México } & 2 \\
\text { Argentina } & 1 \\
\text { España } & 1\end{array}$ & 4 & $\begin{array}{c}7 \\
(5.56 \%)\end{array}$ \\
\hline Consenso & 37 & 1 & $\begin{array}{lr}\text { E.U. } & 1 \\
\text { España } & 10 \\
\text { Argentina } & 6 \\
\text { México } & 14\end{array}$ & 31 & $\begin{array}{c}69 \\
(54.76 \%)\end{array}$ \\
\hline $\begin{array}{l}(1960 \ldots) \\
\text { Revisionista }\end{array}$ & 17 & & $\begin{array}{l}\text { México } \\
\text { España } \\
\text { E.U. }\end{array}$ & 4 & $\begin{array}{c}21 \\
(16.67 \%)\end{array}$ \\
\hline Totales & $\begin{array}{c}72 \\
(57.14 \%)\end{array}$ & $\begin{array}{c}2 \\
(1.59 \%)\end{array}$ & & $\begin{array}{c}52 \\
(41.27 \%)\end{array}$ & $\begin{array}{c}126 \\
(100 \%)\end{array}$ \\
\hline
\end{tabular}

34 Véase bibliografía comentada, núm. 13.

35 Véase bibliografía comentada, núm. 20.

36 Véase bibliografia comentada, núm. 113.

37 Véase bibliografía comentada, núm. 119.

${ }^{38}$ Véase bibliografía comentada, núm. 124. 
preocupación por los marginados y los oprimidos, etcétera), pero reafirma, en lo fundamental, la tesis del consenso.

De las obras revisionistas, salta a la vista la ausencia de traducciones al español (sólo 4, el 19\% de 21 textos, correspondiente al 3.2\% del total global). Se confirma de nuevo el vacío de historias generales escritas en nuestro idioma. La única, la del colombiano Jorge Cárdenas Nannetti: Nueva historia de los Estados Unidos, ${ }^{39}$ que intenta presentar una perspectiva latinoamericana, no hace más que señalar un camino y ratifica la necesidad de proporcionar al lector mexicano un conocimiento más crítico y actualizado de la historia de nuestros vecinos del norte.

\section{PRESENTACION GRAFICA DE LOS TEXTOS REVISADOS}

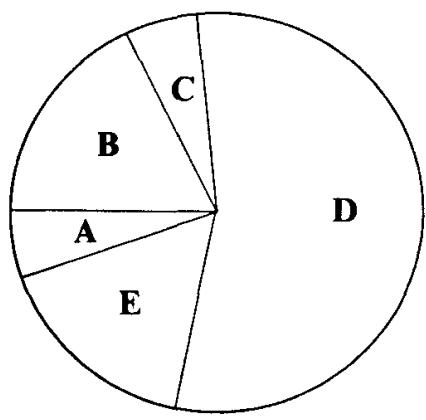

\section{Por corrientes}
A Nacionalista
B Progresista
C Disonantes
D Consenso
E Revisionista

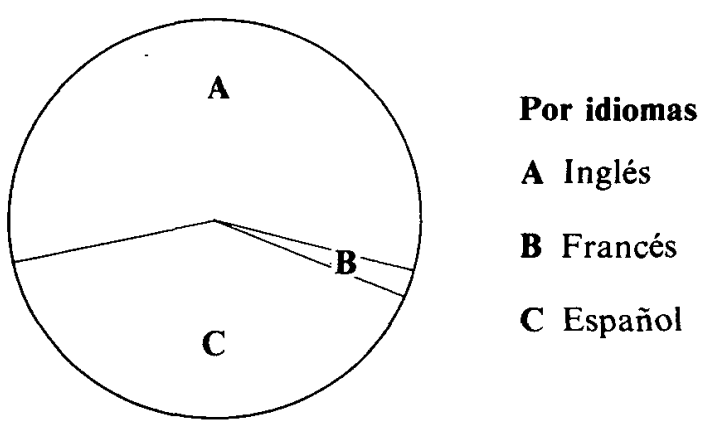

\section{Por nacionalidad de sus autores}

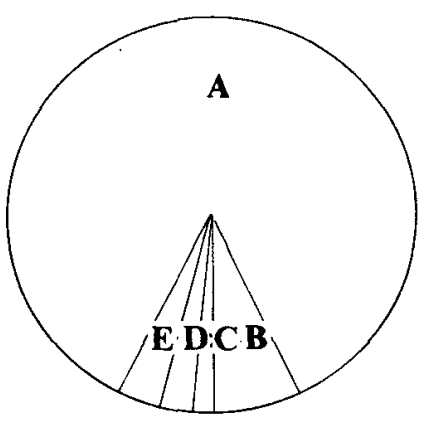

A Norteamericanos

B Franceses

C Alemanes

D Ingleses

E Hispanoamericanos

$$
\begin{aligned}
& 1 \text { español, } \\
& 1 \text { mexicano, } \\
& 1 \text { colombiano y } \\
& 1 \text { chileno. }
\end{aligned}
$$

${ }^{39}$ Véase bibliografía comentada, núm. 110. 
Por idioma en cada una de sus corrientes

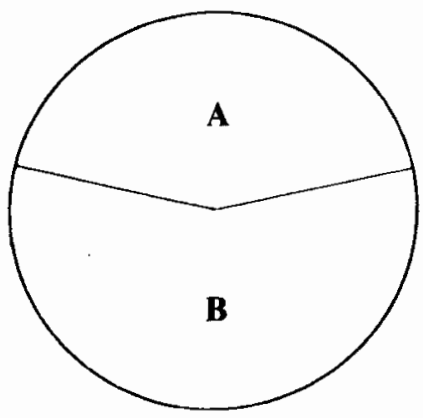

Obras nacionalistas (7 TEXTOS)
A Inglés
$(42.86 \%)$.
B Español
$(57.14 \%)$

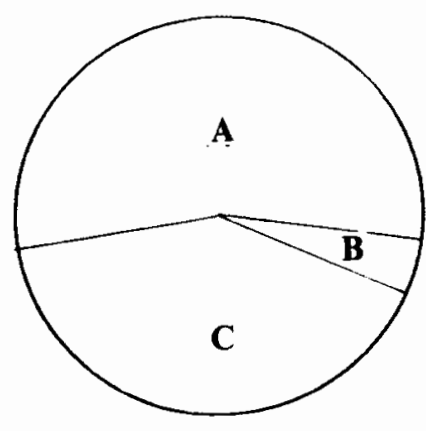

Obras progresistas (22 TEXTOS)
A Inglés
$(54.55 \%)$
B Francés
$(4.55 \%)$
C Español
$(40.90 \%)$

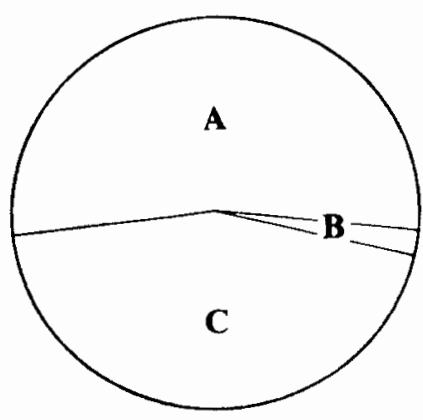

Obras del consenso (69 TEXTOS)
A Inglés
$(53.62 \%)$
B Francés
$(1.45 \%)$
C Español

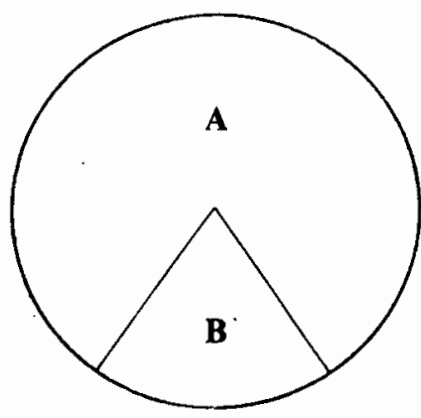

Obras revisionistas (21 TEXTOS)
A Inglés
$(80.95 \%)$.
B Español
(19.05\%). 


\section{Bibliografía Comentada}

\section{Corriente patriótica o nacionalista}

BNAL 1. Bancroft, George, History of the United States, from the

973

BNA. h

COLMEX

$\mathrm{CE}$

973

B213h
Discovery of the American Continent to the Declaration of Independence, Londres, Warne \& Routledge, 1861, 7 vols.

A la manera de Tucídides (La Guerra del Peloponeso), el autor, ex embajador norteamericano en Londres, aspira a presentar con esta obra "un cuadro fiel del progreso de las instituciones norteamericanas" exento de todo partidarismo, sometiendo testimonios y documentos de la época que narra a la férrea disciplina de la "duda metódica" o, como él lo dice, a los "principios del escepticismo histórico".

Bancroft intenta ajustar cuentas con la historiografia tradicional, plagada de errores, basada en rumores, mitos y prejuicios. Pretende, en suma, que sea la primera historia científica de la Unión Americana. Le interesa explicar cómo Norteamérica llegó a ser una nación ideal: próspera por la libre competencia, defensora de las libertades civiles y de la soberania popular. En alguna medida sienta las "grandes verdades" (o ¿mitos?) que hasta hoy en día circulan: sociedad de la opulencia y del progreso, sin deuda pública, prensa libre con el número de diarios más elevado del mundo, leyes iguales para todos, armonía social pese a la constante inmigración, nación civilizadora de los "pueblos bárbaros" comenzando por los indios. Bancroft apunta ya el poderío imperialista de los norteamericanos.

Los siete volúmenes abarcan desde los primeros asentamientos europeos en América (1492), hasta la Declaración de Independencia (1776). Se incluyen índices temático-onomásticos al final de los tomos 2,5, y 7 . Como toda obra que se precie de científica, fuera de los dos ultímos volúmenes, los demás contienen abundantes notas a pie de página.

GZP

BNAL 2. Spencer, Jesse A., Historia de los Estados Unidos, desde 973

SPE

UIA

E178

S64a su primer periodo hasta la administración de Jacobo Buchanan, contada hasta nuestros días por Horacio Greeley, Barcelona, Montaner y Sinán, 1870, 3 vols.

Se trata de la traducción de la obra publicada en inglés en 1866 , dedicada a los "padres fundadores" de la nación con el mismo título. En ella se compara el desarrollo histórico de Norteamérica con el imperio "semidivino" de Roma. Escrita desde una perspectiva liberal individualista, sin embargo observa el gran influjo que ha tenido la "Providencia" en el devenir histórico de la nación estadunidense. La guerra civil había terminado y apenas comenzaban a surgir las grandes corporaciones industriales que pondrían en tela de juicio los ideales de la democracia liberal clásica.

Se trata pues de una obra magna, épica, vista desde la perspectiva de los vencedores, no obstante que el autor a la manera de la escuela historicista alemana, afirma que va "a hacer una pintura fiel del pasado y presente de los Estados Unidos: el porvenir lo tiene Dios escrito en el gran libro donde consigna el destino de la humanidad”. ¡Extraña paradoja! 
La obra contiene hermosos grabados en los que se intercalan los rostros impertérritos de los "salvajes" con los de los "semidioses civilizadores". La narración transcurre año tras año, como si se tratara de una crónica fidedigna de todo lo acontecido desde 1492 hasta 1865 . Se cierra con el discurso pronunciado por el General McClellan con motivo de la inauguración del monumento funerario de West Point el día 15 de junio de 1864. No contiene bibliografia.

BNAL 3. Winsor, Justin, (ed.), Narrative and Cristical History of 970

WIN. n Colaboran varios historiadores de orientación erudita y enciclopédica. Presenta dos tipos de ensayos narrativos, con asuntos como los partidos políticos, la constitución, la diplomacia, etc., y de crítica documental, en los que se incluyen estudios exhaustivos de diversos temas: los retratos de Washington o las fuentes de información para elaborar la historia de los partidos políticos.

El responsable de la recopilación es el bibliotecario de la Universidad de Harvard, secretario de la Sociedad Histórica de Massachusetts y autor de varios ensayos, Justin Winsor.

La obra se inicia con la prehistoria del continente americano para concluir en 1880. Algunos de los capítulos se refieren a la América española, incluyendo a México. Cada tomo tiene ilustraciones, mapas y un indice general de nombres y títulos. Al final del primer volumen incluye una cronologia comparada.

MEL

COlmeX 4. Wilson, Woodrow, Estados Unidos de América, 2a. ed., 973 W754h Nueva York, Harper \& Brothers, 1902, 5 vols

Extenso trabajo sobre la historia norteamericana escrita con el propósito de crear un sentido de nacionalidad. Wilson, quien fuera profesor de la Universidad de Princeton y más tarde presidente de los Estados Unidos (1912-1919), hace en esta obra la exaltación de los valores democráticoliberales con los que identifica a su nación. Abarca desde el periodo anterior a la llegada de los europeos a América hasta fines del siglo XIX.

El libro editado por vez primera en 1901 con el título de $A$ history of the American people, carece de bibliografia. Incluye índice onomástico, apéndices documentales, ilustraciones y mapas.

MTB

BNAL 5. Channing, Edward, A History of the United States, Nue973 CHA. h va York, MacMillan, 1905, 6 vols.

El autor interpreta el desarrollo histórico norteamericano a partir de la conformación del pueblo estadunidense. El surgimiento del estado nacional en los Estados Unidos aparece como parte central del proceso formativo de las fuerzas politicas, militares, institucionales, industriales y sociales que configuran al país. El hilo conductor del texto trata de describir los acontecimientos centrales de la tristoria de los 
Estados Unidos. Channing recrea el devenir histórico, señalando que se compone de fuerzas vivas y no sólo de personajes encumbrados; admite asimismo la posibilidad de haber incurrido en errores, partiendo de la aceptación implícita de que no hay obra científica sin ideología.

El análisis y crítica del texto son más resultado de juicios personales que una revisión bibliográfica exhaustiva. El espacio temporal del libro va desde el siglo XI hasta la primera década del siglo XX. Trabajo extenso, compuesto de 6 volúmenes con mapas, notas a pie de página, indice onomástico y bibliografía por capítulo.

BNAL 6. Fiske, John, Historia de los Estados Unidos, México, Li-

973

FIS. h

UNAM

E178

IF542 brería de la Vda. de C. Bouret, 1909, 430 p.

La intención del autor fue realizar un texto que se adaptara a las necesidades de la enseñanza escolar, razón por la cual es una versión muy condensada.

La reputación de Fiske como historiador nacionalista hizo de esta obra uno de los compendios de historia general de los Estados Unidos mejor conocidos de principios de nuestro siglo. Partiendo de una visión eurocentrista, se presenta como eminentemente descriptiva. Bernardo Calero realizó su traducción al español con el fin de contribuir al entendimiento de las naciones americanas entre sí.

El periodo temporal del texto va de fines del siglo $X V$ a la primera década del siglo $x X$. Incluye mapas, ilustraciones y un breve apéndice.

COLmeX 7. Butler, Nicholas Murray, Los Constructores de los Esta973.04 dos Unidos, Nueva York, s.e., 1940, 370 p. (Biblioteca InteB986c ramericana)

Obra que trata de explicar cómo se fue conformando el ca-

BNAL 973.04

BUTC. C. considerados por el autor como históricamente distintos. Se destaca el idealismo práctico del pueblo norteamericano y a su logro por haberlo plasmado en una legislación, factores ambos que lo particularizan del resto de los pueblos de la Tierra.

El trabajo de Butler es una sintesis de literatura política que, enmarcada en una tendencia nacionalista, pretende destacar la "libertad politica que el pueblo americano se ha reservado a sí mismo" (prefacio, p. XXIII). Haciendo una interpretación que mezcla la historia constitucional de los Estados Unidos con el desenvolvimiento de personalidades conspicuas, el autor cae en la exaltación de la individualidad y convierte su obra en un trabajo ideológico.

El texto puede ser útil para consultar cuestiones específicas respecto a ciertos personajes norteamericanos. El libro abarca de 1772 a 1921 y contiene apéndice, mapas, indice alfabético y un prefacio realizado por Jorge Roa, profesor de la Universidad de La Habana (Título en inglés: Building the American Nation, 1923). 


\title{
Corriente progresista
}

\begin{abstract}
BBF 8. Turner, Frederick Jackson, La Frontera en la historia S americana, Madrid, Castilla, 1961, 326 p.

978

TUR

El texto, editado por primera vez en inglés en 1920 con el título The Frontier in American History es el resultado BNAL de la compilación de 13 artículos publicados a partir de 973 1893. Su hilo conductor es la importancia de la "frontera" TUR.f en la historia de los Estados Unidos. Abarca un periodo UIA comprendido entre finales del siglo XVII y la primera década E179.5 del siglo XX.

T95f. Anuncia el inicio de una de las más importantes corrientes historiográficas norteamericanas del presente siglo que trata de explicar el desarrollo histórico a través de los factores geográficos y regionales y que devendrá en la escuela progresista. Define la frontera como una línea discontinua y movediza que delimita la colonización de los pioneros que a su vez aparece como institución que fundamenta y origina a la totalidad de la sociedad norteamericana y además es el germen del ideal de su democracia.

La obra no hace alusión a periodos históricos específicos y funciona más bien como una justificación a la expansión capitalista de los Estados Unidos, sosteniendo una tesis nacionalista. Incluye bibliografía.
\end{abstract}

SNG

UNAM 9. Muzzey, David Sevid Saville An American History, BosEl78 ton, Ginn, 1911,662 p.

IM99 Obra escrita con la idea de dar énfasis a los factores del desarrollo nacional más destacados y vitales, tales como la discusión del poder federal y la Constitución. Subraya que la frontera móvil es la "fuerza constante y potente de la historia".

Es didáctica, amena y está bien documentada. Se divide en ocho partes con referencias bibliográficas al final de cada capítulo. Incluye un extenso apéndice con la Declaración de Independencia, la Constitución y enmiendas, los estados de la Unión, los presidentes y gabinetes. Contiene indice, ilustraciones y mapas.

MEL

UIA 10. Faulkner, Harold Underwood, American Economic HC103 History, 6a. ed., Nueva York, Harper \& Brothers, 1949, F3a $812 \mathrm{p}$.

Publicado por primera vez en 1924, fue corregido y ampliado en ediciones sucesivas. Se extiende desde los antecedentes europeos de la colonización de Norteamérica hasta los años que siguieron a la segunda guerra mundial.

Faulkner estudia la historia de su país desde un punto de vista económico, sin que por ello pierda su carácter narrativo. Al parecer, la ve como un todo y no se desvía hacia un materialismo parcial. El editor señala que los que lean esta obra estarán mejor preparados para enfrentar los más complicados problemas económicos y sociales del futuro.

Los mapas, cuadros y cuarenta ilustraciones que acompañan al texto 
ilustran el desarrollo económico norteamericano con claridad; la extensa bibliografia lo completa y refuerza.

COLMEX 11. Muzzey, David Saville, The United States of America, 973 2a. ed., Boston, Ginn, 1933, 2 vols.

M994u El autor toma como parteaguas de la historia de los EstaBNAL dos Unidos el acontecimiento de la guerra civil. El texto es973 MUZ.v tá dirigido a estudiantes de nivel universitario y fue editado por primera vez en 1924. El primer volumen abarca del gobierno de Jefferson, a principios del siglo XIX, al estallido de la guerra de secesión. Esta --según Muzzey - es una época marcada por la confirmación de los fundamentos territoriales, politicos y constitucionales del poder nacional. La expansión hacia el oeste, la ampliación de la base democrática y la defensa de los principios federalistas, marcan la impronta de esta etapa.

El segundo volumen estudia desde la guerra civil hasta la segunda década del siglo XX. El tema es, al igual que en el primero, el desarrollo de la "democracia americana", pero con nuevas condiciones y frente a problemas distintos. Esta fase, cuya cuestión fundamental es la división entre el este y el oeste se caracteriza por la necesidad de un creciente control del gobierno federal sobre las grandes empresas, el abandono de la politica aislacionista y la confirmación de los Estados Unidos como potencia mundial. El autor subraya aquí la importancia de los aspectos económico e internacionales.

Muzzey estima que la democracia no es algo dado y que la lucha por establecerla ha sido continua en la historia de los Estados Unidos. La obra contiene bibliografía comentada por capítulos, índice onomástico y una lista de mapas.

MTB

COLMEX 12. Pasquet, D. Histoire politique et sociale du peuple améri973

P284h cain, París, Picard, 1924, 2 vols.

Con la intención de llenar una laguna en el medio francés, este trabajo de síntesis detallada va a presentar como héroe de la historia, no a Lincoln o Washington, sino al "pueblo norteamericano" en su conjunto. El autor no oculta su asombro de que en poco más de un siglo los Estados Unidos se pusieran al frente del capitalismo industrial. De alguna manera, para Pasquet, la explicación de los hechos sociales que ahi constan se encuentra en las condiciones geográficas.

La obra está dividida en dos volúmenes, el primero transcurre hasta 1830, y el segundo, hasta 1931. Incluye una extensa bibliografía - de todos los autores conocidos hasta ese momento-, mapas e ilustraciones y un índice alfabético. 
BNAL

973

BEA.h.

U1A

110835

110830

Es la traducción al español hecha por Rubén Dario hijo, de The Rise of American Civilization. Consta de 31 capítulos distribuidos en 4 volúmenes. Fue editada por primera vez en 1930. Realizada en estilo sencillo, abarca desde finales del siglo XV hasta la segunda década del siglo XX. Pretende mostrar el desarrollo histórico de los Estados Unidos desde una perspectiva de conjunto.

Beard intenta resaltar la dinámica propia de la sociedad norteamericana, realizando un trabajo autocrítico que conlleva una visión profunda, amplia y realista de su historia.

La posición asumida por el autor es moderada en lo que respecta a su visión del movimiento proconstitucionalista y va radicalizándose a lo largo del texto, al grado de considerar a la guerra civil "como un irreprimible conflicto entre dos sectores sociales, cuyos efectos han traído un cambio al vórtice político de la sociedad norteamericana" (del prefacio).

Destacan la incorporación de acontecimientos socio-económicos y culturales dentro de una coherencia en la narración. El libro contiene capítulos relevantes como el VIII, "Nacimiento de los Partidos Políticos" y el XXXI, "La Era del Maquinismo". Carece de anexos bibliográficos y de notas.

SNG

UNAM 14. Kirkland, Edward Chase, Historia Económica de EstaHCl03 dos Unidos, Trad. de Eugenio Imaz, 2a. ed., México, FCE, K54 1947,840 p.

UIA

$\mathrm{HC} 103$

$\mathrm{K} 54$

La obra, editada por primera vez en 1932, al parecer ampliada en 1939, proporciona un panorama general del desarrollo económico de los Estados Unidos. Dentro de una tradición progresista, su autor, miembro de la primera escuela norteamericana de historia económica, intenta relacionar, con detalle y profundidad, las acciones económicas con los intereses de las distintas clases sociales en cada época.

Sin prefacio, Kirkland entra en materia y divide el texto en diecisiete capítulos que cubren desde los viajes de descubrimiento y exploración de América que comienzan a fines del siglo $\mathrm{xV}$, hasta la politica del Nuevo Trato que Franklin D. Roosevelt inicia en 1933. Cada capitulo incluye bibliografía brevemente comentada. El lenguaje es claro y directo y el desarrollo de las ideas y argumentos es ordenado y lógico. Incluye algunos mapas y cuadros de información económica.

MEL

COLMEX 15. Wood, Clement, $A$ Complete History of the United Sta973 W874c tes, 4a. ed., Ohio, The World Publishing, 1941, 625 p.

Obra de divulgación elaborada con la idea de que la "historia es la peregrinación registrada del alma humana, expresada en sus palabras y hechos", de tal manera que carece de profundidad en los temas. Con estilo simple y sencillo se elabora una historia descriptiva de héroes y hombres destacados, donde las únicas diferencias se limitan al demócrata contra el artistócrata o al idealista contra el realista. Es una historia de corte progresista que reconoce las contradicciones existentes en la sociedad norteamericana, pero que a su vez no propone ideas para su resolución, cayendo en la justificación y 
descripción de los acontecimientos.

El texto, editado por primera vez en 1936, abarca un periodo que se inicia con el establecimiento de las 13 colonias para concluir en la cuarta década del siglo XX. Incluye una bibliografía general y una especializada por capitulos, una cronología hasta 1940, apéndice documental con la Constitución, Declaración de Independencia y la Doctrina Monroe.

En la contraportada se incluye un mapa que establece los límites territoriales de los Estados Unidos en diversas épocas históricas, señalando años y razones de la expansión. En cuanto a los territorios arrebatados a México se explica que en 1848 fueron "cedidos a los Estados Unidos por México al final de la guerra mexicana".

MEL-SNG

COLMEX 16. Faulkner, Harold Underwood, American Political and 973 Social History, 6a. ed., Nueva York, Appleton-CenturyF263am Crofts, $1952,984 \mathrm{p}$.

Dirigida a estudiantes de nivel universitario, la obra intenta ahondar en aspectos políticos y sociales de la historia de los Estados Unidos, sin dejar de lado los factores económicos. Editada por primera vez en 1937, revisada y ampliada posteriormente, se extiende desde los antecedentes europeos de la colonización en América (siglo XV) hasta los problemas que siguen a la segunda guerra mundial (19451952).

Faulkner presenta la historia norteamericana enmarcada por el progresismo. Ve la lucha por la independencia de su pais como una revolución que tuvo tremendos efectos sociales, no sólo políticos, y a la guerra civil como un conflicto "irreprimible", causado por los diferentes intereses económicos en pugna.

El libro hace, al terminar cada capítulo, una serie de sugerencias bibliográficas con el propósito de que se complete lo dicho en el texto y se aliente la discusión en el salón de clase. Dedica el último capítulo a una completa bibliografia general. Cuenta con ilustraciones, mapas y cuadros y al final reproduce la Constitución de los Estados Unidos y presenta un índice onomástico.

MEL-ARSA

COLMEX 17. Woodward, William E., A New American History, 973

W912n Nueva York, The Literary Guild, 1937, 900 p.

La pretensión del autor es mostrar el surgimiento y desarrollo histórico norteamericano como parte integral de un proceso social continuo. La historia se presenta como el registro, a través del tiempo, del conflicto entre el hombre y sus circunstancias. Así, Woodward hace referencia a las diferencias entre los seres humanos, debido a sus distintas capacidades y herencia, pero sostiene con firmeza que el devenir histórico está sujeto a un ciclo por el cual se observa que "la historia se repite" permanentemente.

La obra evade el concepto de cambio a través de la historia y prefiere dar énfasis al reformismo. Su tema central gira alrededor de las ideas políticas expresadas por personalidades y hechos históricos, haciendo un intento de que la importancia de los mismos hable per se. Dirigida a 
un amplio público, muestra el crecimiento del "American spirit" y el desenvolvimiento de sus instituciones.

Dividida en 4 partes - Las colonias; La nación adolescente; Hacia el oeste; El surgimiento de los plutócratas -, narra desde la expedición de Colón a América, a finales del siglo $\mathrm{XV}$, hasta la administración de Hoover, en los años treinta de nuestro siglo. Incluye una bibliografía general y un indice temático onomástico.

SNG

COLMEX '18. Nichols, Jeannette P. y Roy F. Nichols, The growth of 973 American democracy, Nueva York, Appleton Century, N626g $1939,819 \mathrm{p}$.

Para los autores, los Estados Unidos son la única república que permite el autodesarrollo del individuo mediante la propia voluntad. La lucha por el poder ha sido propiciada por las riquezas naturales y el deseo de libertad y felicidad. El punto crítico de su historia son los nuevos desafios para la democracia: en una sociedad industrial, ies posible la realización de la libertad original?

Después de un rápido repaso de la vida colonial (1575-1763), se llega a la descripción del proceso de independencia (1763-1819) y se concentra a continuación en la era del expansionismo y la guerra de secesión. El periodo de la "reconstrucción" (1865-1878) se presenta como un "impasse" violento, puerta de entrada a la formación de los "trusts" industriales (1978-1900). En la fase imperialista, los autores van a dar gran énfasis a los reformadores sociales, cuya expresión culminante queda simbolizada en el proyecto del "New Deal", capítulo que cierra la obra.

El texto puede revestir un interés especial en cuanto que está escrito desde la óptica del proyecto de F. D. Roosevelt. Además de una bibliografía amplia en cada uno de los grandes apartados que le dan forma, incluye al final un índice analítico.

BNAL 19. Hacker, Louis Morton, Proceso y triunfo del capita330.973 lismo norteamericano, Buenos Aires, Sudamericana, 1942, Hac.p. 410 p.

COLMEX En una interpretación que privilegia los factores econó380. 973 micos, Hacker, progresista que toma algunos elementos del H118p. marxismo, presenta la historia norteamericana como el proBIM ceso de desarrollo del capitalismo en los Estados Unidos de 330.122 Norteamérica. Difiere en buena medida de la visión del "exHAC.p. cepcionalismo" norteamericano y sostiene que, a pesar de que en algunos aspectos la historia de los Estados Unidos de América ha seguido modelos únicos y originales es, en general, un reflejo del capitalismo europeo del cual es heredera.

La obra, editada por primera vez en 1940, es una visión nostálgica del capitalismo de libre competencia al cual considera creativo, progresista, de campu abierto; que, sin embargo, ha tenido que dar paso al capitalismo linanciero, donde los grandes monopolios tienen el control. El libro fue escrito durante la gran depresión de los años treinta.

Trabajo dirigido a un público de conocedores, abarca desde los ante- 
cedentes europeos hasta el periodo del "New Deal" (1933 ss). Presenta al final una lista de sugerencias bibliográficas.

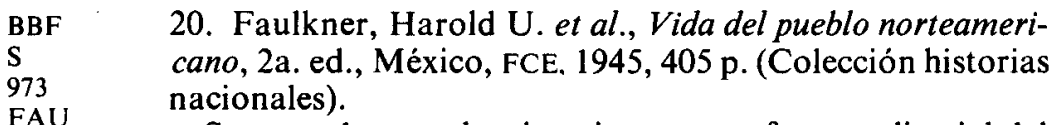

FAU Se trata de una obra inscrita en un esfuerzo editorial del COLMEX FCE por dar a conocer las historias generales de otros países 973 al público mexicano. Esta edición en particular estuvo al F263v cuidado del historiador Daniel Cosío Villegas. El original BNAL inglés se titula The American Way of Life y fue publicado por 973 FAU.v Desde una perspectiva reformista, los autores de este libro dibujan un cuadro histórico de la sociedad norteamericana, en el que de forma un tanto desarticulada, desfilan tópicos tales como el clima, la geografía, los recursos naturales, el desarrollo demográfico, el avance tecnológico, la vida política y las crisis sociales. En especial, las crisis económicas no encuentran una explicación satisfactoria. Lo importante es la afirmación de que "las ganancias han sido mayores que las pérdidas" (p. 293-4).

En plena confrontación bélica de la segunda guerra mundial, la historia presentada es una defensa del "sistema americano" desde el punto de vista del "New Deal". De ahí probablemente el énfasis dado, a través de los 35 capítulos que componen la obra, a las relaciones que se fueron dando entre el gobierno y la iniciativa privada, hasta la formación de un gobierno cada vez más interventor de la economía y de las relaciones sociales, tanto a nivel nacional como internacional. A primera vista, por su estilo descriptivo un tanto plano, el texto parece inofensivo. Sólo deja ver su intención didáctica de mostrar cómo los Estados Unidos se convirtieron en una potencia industrial con una forma de gobierno democrática peculiar.

Sin seguir una periodización tradicional, la obra cubre las épocas que van desde los primeros asentamientos europeos en Norteamérica hasta aquélla en que se pone en marcha el proyecto del "New Deal" (década de 1930). No contiene notas ni bibliografía alguna.

COLMEX 21. Beard, Charles Austin, A Basic History of the United $973 \quad$ States, Filadelfia, Blakiston, 1944, 504 p.

B368b El periodo comprendido en la obra abarca del siglo XVI BNAL hasta la primera mitad del siglo XIX, teniendo como 973 objetivo central la interpretación histórica de los sucesos BEA.b clave en la conformación de los Estados Unidos. La contiUNAM nuidad del relato y su lenguaje sencillo hacen que el texto E178 sea accesible a cualquier lector, además de ser una obra B39 compacta.

Beard realiza una serie de juicios con el propósito de hacer inteligible el proceso de desarrollo de la sociedad norteamericana; resaltan los aspectos políticos y económicos, así como las diferencias entre la problemática rural y urbana.

Varios capítulos destacan del conjunto de la obra, como el VII: "Dos sistemas e ideologías en conflicto", p. 87 y el XXIII: "Revueltas en 
contra del crecimiento plutocrático del poder político"; p. 374. Además, contiene una somera lista bibliográfica.

COLMEX 22. Hockett, H. Carey y A. Meier Schlesinger, Evolución 973 política y social de los Estados Unidos, Trad. de A.J. Brusol, H685e Buenos Aires, Guillermo Kraft, 1954, 2 vols. (Colección Cúpula).

El libro, que abarca desde las primeras exploraciones europeas en América hasta la crisis de Corea a mediados del siglo $\mathrm{XX}$, consta de dos volúmenes; el primero (1492-1865) escrito por H. Carey Hockett y el segundo (1865-1951) por A. Meier Schlesinger. Se trata no sólo de una obra muy completa en tanto que comprende aspectos políticos, económicos, sociales y culturales, sino también de fácil lectura gracias al estilo claro y directo y a la acertada traducción. Lamentablemente, carece de un buen aparato crítico. Tampoco indica la fecha de la primera edición en inglés, a la que se tituló Political and social growth of the American people.

Los autores piensan que la historia de los Estados Unidos es la de una democracia que, desde sus inicios, ha enfrentado una serie de conflictos, obstáculo para su plena realización. Estos conflictos se tratan a lo largo del texto; por ejemplo, las dificultades relacionadas con la expansión territorial y con la asimilación de los inmigrantes, los enfrentamientos entre intereses locales y nacionales, la contienda entre el capital y el trabajo, etc. Empero, Hockett y Schlesinger no niegan su fe en el progreso. Creen que, pese a las dificultades, el experimento democrático norteamericano ha sobrevivido y ha justificado su existencia como inspiración continua para el resto del mundo.

ARSA

COLMEX 23. Hockett, Homer C. y A. M. Schlesinger Land of the 973 Free, a short history of the American people, Nueva York, MacMillan, 1945, 765 p.

Obra de historia general de los Estados Unidos publicada en 1945 durante el periodo final de la segunda guerra mundial, que aprovecha la coyuntura política para fomentar la conciencia y el orgullo nacionalistas, elementos que conllevan la transición de la historiografía progresista hacia la neoconservadora.

Sus autores plantean al lector los problemas ante los cuales se ha enfrentado la democracia norteamericana y su constante capacidad de adaptación, "misma que la ha erigido como ejemplo a seguir por otras naciones". El mismo título sugiere que es un texto de gran contenido ideológico ya que carece de juicios críticos, redundando en conceptos tan subjetivos como el que considera en el prólogo que "los estadunidenses deben ser buenos patriotas, como buenos ciudadanos del mundo".

El texto, que describe el desarrollo histórico norteamericano recalcando su aspecto sociopolítico, abarca desde el siglo XVIII hasta la cuarta década de la presente centuria. En estilo sencillo, el libro es una versión sintética - con algunas modificaciones en su estructura- de la misma obra en 2 volúmenes de Hockett y Schlesinger (véase núm. 22). En 
cada capítulo presenta una selección bibliográfica, además de mapas e ilustraciones.

SNG

COLMEX 24. Hacker, Louis M., The shaping of the American tradi-

973

H118s

BNAL

973

HAC.S

$\mathrm{BBF}$

973

H118s

tion, Nueva York, Columbia University Press, 1947, 2 vols.

Hacker enfoca la historia norteamericana desde un punto de vista principalmente económico, sin dejar de lado los aspectos politicos y sociales. Considera que, además de la tradicional teoría de la frontera, la comprensión completa de la historia de los Estados Unidos sólo se logrará si se toman en cuenta otros factores: la libertad religiosa que hizo posible la existencia de un clima más abierto a la experimentación social; la libertad de empresa que liberó a la nación de la carga de un pasado feudal; el estado débil que permitió el respeto por el derecho a la vida, la libertad y la búsqueda de la felicidad; el ideal de igualdad de oportunidades económicas y sociales, etcétera.

Dentro de una tradición progresista, Hacker cree que la historia de su país es una historia de éxitos, cuyos sujetos no sólo han desarrollado los recursos del territorio y transformado una pequeña comunidad en una potencia mundial, sino que también han demostrado que la democracia es un sistema que puede funcionar. Emplea algunos conceptos marxistas en la elaboración de su texto.

El libro abarca desde los antecedentes europeos de las colonias inglesas de América del Norte hasta los años de la segunda guerra mundial. Cada una de sus secciones se complementa con documentos ilustrativos sobre "la mente americana", "el escenario americano", "los problemas americanos" y "los Estados Unidos y el mundo".

ARSA

BNAL

917.3

SCH.r.

BBF

$\mathrm{S}$

917.3

$\mathrm{S} 342 \mathrm{r}$
25. Schlesinger, Arthur Meier, Rumbos de la Historia Norteamericana, Buenos Aires, Hobbs-Sudamericana, 1964, 373 p.

Más que una obra de historia general, el texto constituye un análisis de la personalidad sociohistórica de los norteamericanos y sus instituciones políticas.

Basado en una división temática que denota su postura progresista, el autor examina un espacio temporal que parte del estudio de las características de los primeros colonos europeos en Norteamérica, hasta concluir en la época de la guerra fría. Cabe mencionar que Schlesinger es uno de los historiadores norteamericanos mejor conocidos de los años 40 .

El libro aparece originalmente en inglés en el año de 1949 bajo el título de: Paths to the Present. La traducción al español carece de prólogo. Incluye un apartado de sugerencias bibliográficas por capítulo e índice onomástico.

SNG 
Editada por primera vez en 1953, la presente obra se basa en la idea de que los eventos más importantes de la historia norteamericana pueden ser presentados gráficamente en poco espacio. Así, los autores han entregado una especie de atlas histórico, que incluye por un lado una breve sintesis y por el otro, mapas, caricaturas, gráficas, etc., que ilustran cada uno de los periodos en que se divide el texto.

Componen el libro 9 unidades en las que se advierte un énfasis especial en los efectos de la revolución industrial, presentes en la vida política, cultural y en las relaciones exteriores. Se cierra con un capitulo destinado a Estados Unidos como potencia mundial y a su responsabilidad, en la época de la guerra fría, para salvaguardar la democracia.

El trabajo comienza examinando las causas del descubrimiento de América y los primeros intentos de colonización y termina, en el marco de la disputa por el liderazgo mundial de la guerra fría, con el tema sobre la conquista del espacio. Incluye al final el texto de la Constitución, referencias documentales y un índice onomástico. Cada unidad contiene un breve sumario y un cuestionario de índole escolar.

GZP

COLMEX 27. Miller, William, Historia de los Estados Unidos, Mexi973 M652he Obra expresamente dirigida "al lector general de criterio maduro" (p. 15) que pretende explorar el pasado por medio de nuevas orientaciones para hacer accesible el porqué de la historia y con ello servir, según el autor, de instrumento para comprender el presente y clarificar las metas a futuro de la sociedad norteamericana.

Basada en varias de las historias norteamericanas modernas más objetivas - tales como las de Beard, Schlesinger y Parrington-, la obra abarca toda una gama de cuestiones cuya urdimbre central es económica, pero dando mayor importancia a las fuerzas sociales, intelectuales y políticas que, consideradas en una perspectiva global, interactúan constantemente en la conformación de la nación norteamericana. Miller acentúa la participación popular en el proceso histórico de los Estados Unidos, dejando un tanto al margen la individualidad de los personajes de la historia.

El texto abarca desde el siglo XV hasta la primera mitad del siglo XX; apareció en inglés en 1958 con el título $A$ history of the United States. Contiene algunas notas a pie de página y su traducción al español presenta cierta dificultad por el manejo de vocablos poco usuales.

SNG

COLMEX 28. Allen, Harry Cranbrook, Historia de los Estados Unidos 973 de América, Buenos Aires, Paidós, 1969, 2 vols.

A426h El autor se propone en esta obra argumentar acerca del UIA desarrollo histórico y político norteamericano, partiendo E178 de una postura progresista. El hilo conductor está constituiA39 do de manera fundamental por datos económicos y politicos, marginando el aspecto social que sólo se menciona referencialmente.

Allen afirma que el crecimiento y desarrollo de los Estados Unidos sólo puede entenderse si se tiene una visión global de su proceso histórico, el cual pretende describir de ma- 
nera imparcial, reconociendo lo difícil de su tarea por la abundancia de fuentes secundarias que obstaculizan una selección óptima.

El libro abarca del siglo XV hasta la primera mitad del siglo XX. La traducción al español es de difícil comprensión. Aunque carece de una bibliografía amplia, puede hacer aportes considerables para trabajos especificos acerca de cuestiones políticas y económicas. La versión original en inglés data de 1964 y lleva como título The United States of America. A Concise History. .

BBF 29. Beard, Charles, The Beards' New Basic History of the

973

BEA

\section{Corriente del consenso o neoconservadora}

COLMEX

973

$\mathrm{V} 2144 \mathrm{e}$

UIA

E178

V 253

BBF

S

973

V261e
United States, Nueva York, Doubleday, 1968, 571 p.

Obra que intenta interpretar el devenir histórico norteamericano a través de sus actividades, ideas e intereses fundamentales, factores todos determinantes del desarrollo estadunidense contemporáneo. Su autor es uno de los más brillantes exponentes de la historiografía progresista.

Aun siendo un libro dirigido al público en general, no es un simple sumario de los trabajos previos de Beard, pues éste trata de emitir nuevos juicios históricos, producto de más de cuarenta años de estudio e investigación detallada de la multiplicidad de componentes de la sociedad de los Estados Unidos. Tiene como antecedente a la Basic History of the U.S., (véase núm. 21) siendo esta nueva versión corregida y actualizada por el hijo del auWilliam Beard.

Su lenguaje es sencillo; el relato se inicia en el siglo $x v$ y termina a finales de la sexta década del siglo XX; destaca los aspectos políticos y económicos que inciden en la formación social norteamericana. Contiene mapas, diagramas, apéndice documental, ilustraciones y una cronología.

SNG

30. Van Loon, Hendrick W., Los Estados Unidos, historia de la gran república del norte, Buenos Aires, Claridad, 1944, 400 p. (Biblioteca la tierra y el hombre, 2).

El autor nos presenta una versión más bien pesimista de la historia norteamericana. Las ilusiones perdidas de su generación tratan de encontrar nueva esperanza en la generación joven, a quien parece estar dirigido el texto.

Sin aportar nuevos conocimientos sobre la historia de los Estados Unidos, la originalidad de esta obra radica en su estilo narrativo, escrita a la manera de una leyenda o cuento infantil con una preocupación moral honda. Mantiene siempre un tono irónico: el capítulo 40 referido a la pérdida de la mitad del territorio mexicano se titula: "Santa Ana, presidente de México, aprende la exactitud de la ley de que el vacío repugna a la naturaleza". Los capítulos (52 en total) son breves, asi como los párrafos y las ilustraciones se adecuan bien al estilo literario.

El relato, siempre dentro del contexto de la historia europea, trans- 
curre desde la primera llegada de los europeos a tierras americanaś hasta la época de la segunda guerra mundial, aunque no hay que esperar una periodización exacta. Se trata eminentemente de una presentación satírica de algunos de los mitos que rodean a la historia estadunidense. Su visión pesimista está permeada por el clímax y decadencia (grandes guerras destructoras) de la sociedad urbano-industrial. Así, para el autor, la historia norteamericana no es "gloriosa", sino sólo "interesante".

La obra, que carece de aparato crítico, fue publicada originalmente en 1942 bajo el título The Story of America.

GZP

BBF

$S$

973

HOF

31. Hofstadter, Richard, La tradición política norteamericana y los hombres que la forjaron, Barcelona, Seix-Barral, 1969, 477 p. (Biblioteca breve de bolsillo).

$\mathrm{Si}$ se quiere tener una introducción a la historia política de los Estados Unidos, Hofstadter ha entregado con este libro - recientemente reeditado en México por FCE - una de las mejores.

Proveniente el autor de la tradición progresista, su texto se sitúa en la confrontación con esta corriente; en particular con tres de sus más grandes exponentes: Beard, Parrington y Turner. El objetivo central de la serie de biografías políticas (en forma de ensayo) que componen este trabajo es desmitificar las figuras que habian sido puestas en el pedestal durante la época del "New Deal", favorecidas por la interpretación progresista o jeffersoniana de la historia que condujo a una nueva forma de nacionalismo cultural bajo "auspicios izquierdistas".

La obra arranca con los "padres fundadores", pasando por Jefferson, Jackson, Calhoun, Lincoln, Bryan, T. Roosevelt, Wilson, Hoover hasta F. D. Roosevelt. Publicada originalmente en 1948 con el título The American political tradition and the men who made it, incluye al final un amplio ensayo bibliográfico y un índice analítico.

GZP

COLMEX 330.973

$\mathrm{H} 877 \mathrm{n}$

BNAL 973

HUB.n 1981
32. Huberman, Leo, Nosotros, el puéblo. Historia de los Estados Unidos, 3a. ed., México, Nuestro Tiempo, 1984, 470 p.

Presentación de la historia de los Estados Unidos desde la perspectiva del materialismo histórico, dirigida a un amplio público.

Su mérito y característica fundamental es la sencillez y plasticidad de las imágenes con que plantea los procesos sociales y económicos de la historia norteamericana. Siguiendo los relatos accesibles y vívidos, las descripciones precisas y las anécdotas ilustrativas, se obtiene una visión esclarecedora y a menudo hermosa de cómo se desarrollaron en el país las actividades productivas y se formó el mercado, de cómo eran las relaciones de producción, la vida de los obreros, sus luchas, etc., todo ello apoyado por los testimonios de las clases sin privilegios.

Ofrece una excelente oportunidad de acercarse a la historia de los Estados Unidos para aquéllos que deseen hacerlo por primera vez. 
$\begin{array}{ll}\text { BBF } & \text { 33. Thistlethwaite, Frank, El gran experimento. Introduc- } \\ \text { S } & \text { ción a la historia del pueblo norteamericano, México, Letras, } \\ 973 & 1959,396 \text { p. }\end{array}$

Se trata de una obra de sintesis interpretativa escrita por

UIA

E178

T35

un profesor de la Universidad de Cambridge para el público

BNAL

973

THI.g inglés. Subyacen ideas de Turner y Handlin y la tesis de la singularidad de la democracia norteamericana. La idea de la "frontera móvil" acompaña toda la lectura, planteando al final la posibilidad de la frontera final o infranqueable.

Thistlethwaite tiene el mérito de visualizar el hecho de que la historia norteamericana, en términos demográficos, económicos y politicos, no se entiende si se aísla del desarrollo histórico de Inglaterra, al menos hasta los umbrales del siglo xx. Se podría decir que Estados Unidos es "el gran experimento" europeo en tierras americanas.

El autor sugiere que la historia norteamericana implica un doble movimiento: primero el escenario principal tiene lugar en la cuenca del Atlántico dados los estrechos vínculos con Inglaterra y, paulatinamente, el centro de atención se irá trasladando a la línea de la frontera continental, donde irá apareciendo el "hombre nuevo". Sin embargo, explica Thistlethwaite, este "hombre" no hubiera sido posible sin el capital y los recursos ingleses. La pugna entre la "idea democrática" y la esclavitud quedará resuelta con la guerra civil (1850-1875), punto de arranque de la segunda gran etapa caracterizada por la aparición de los monopolios, las grandes olas migratorias y la renovación de dicha "idea" en base a la hegemonización de las grandes corporaciones (1890-1920). El texto se cierra con un capitulo dedicado a la democracia en el mundo moderno, habiendo comenzado con la sociedad norteamericana en la época de Jorge III. No contiene bibliografía, sólo un indice analítico al final.

La primera edición en inglés data en 1955, misma que aparece bajo el título de The Great Experiment; an introduction to the history of the American people.

GZP

COLMEX 34. Hofstadter, Richard et al., The United States: The His973 tory of a Republic, 9a. ed., Englewood Cliffs, Prentice Hall, H713u $1961,812 \mathrm{p}$.

Este libro, reimpreso nueve veces entre 1957, año de su primera edición y 1961, es una síntesis muy completa de la historia de los Estados Unidos de América. Fue dedicado por Hofstadter a la gente de su generación, al considerar que la comprensión de lo que son los norteamericanos debe buscarse en el examen de sus instituciones y prácticas politicas. El enfoque politico no excluye sin embargo el estudio de la economía, la estructura social y la ideología.

La obra - cuyo autor tiene gran relevancia dentro de la historiografía norteamericana-, está narrada en estilo ameno y abarca désde el descubrimiento de América hasta mediados del siglo XX. Presenta bibliografía e indice onomástico.

MTB

COLMEX 35. Hofstadter, Richard et al., The American Republic, En973

H713am glewood Cliffs, Prentice Hall, 1959, 2 vols.

A más de ampliar, el texto reelabora, revisa e interpreta 
con mayor profundidad la obra anterior de este autor clásico de la historiografia norteamericana: The United States; The History of a Republic (1957).

Los nuevos capítulos del volumen I comprenden una discusión sobre el oeste prerrevolucionario, un examen del periodo jeffersoniano y del significado de la Constitución y un estudio sobre la renuenciáa al compromiso de los dos bandos durante la guerra civil.

El volumen II contiene un estudio sobre trabajadores inmigrantes y nativos, una revisión de los movimientos de los granjeros, dos capítulos sobre la relación sociedad-industria y uno sobre literatura contemporánea.

Hofstadter sostiene una postura crítica respecto a la corriente progresista a la cual perteneció, sin que ello implique su alineación con la tendencia del consenso.

Los libros están dirigidos a estudiantes universitarios, a la "generación del presente", a quienes pretenden dar una visión más vívida de su pasado, de su presente y de su desafiante futuro. Contiene ilustraciones, mapas, índice onomástico y una lista de lecturas al final de cada capítulo.

MTB

COLMEX 36. Hofstadter, Richard et al., The Structure of American 973

H713s History, Englewood Cliffs, Prentice Hall, 1964, 416 p.

Obra corta basada en The United States: The History of a Republic (1957) y The American Republic (1959) véase núms. 34 y 35 ), especialmente en el aspecto político. Contiene un nuevo capitulo sobre el descubrimiento de América y otro en el que se analiza al sur antes de la guerra civil.

El objeto es presentar a los estudiantes universitarios una historia politica de los Estados Unidos compacta, cometido que logra cabalmente, considerando a la vez la interrelación del factor político con la economía y la sociedad. A pesar de la brevedad del libro, se aprecia el espíritu crítico del autor que penetra en las contradicciones del desarrollo histórico norteamericano, dejando de lado la apología de las instituciones.

Contiene mapas, ilustraciones y al final de cada capitulo, útiles sumarios, una lista de sugerencias bibliográficas e indice onomástico. Abarca desde el descubrimiento de América hasta el asesinato del presidente Kennedy en 1963.

MTB

COLMEX 37. Morison, Samuel Eliot, The Oxford history of the Uni973 ted States, 1783-1917, Londres Oxford University Press, M8610 1928, 2 vols. BNAL Samuel E. Morison, norteamericano, escribió esta obra
973 . cuando impartía la cátedra de historia de los Estados UniMOR.Ox dos en la Universidad de Oxford.

UIA Su objeto era dar a conocer el desarrollo histórico de su E178 país natal, relatándolo de tal manera que los lectores adquiM8 riesen la capacidad de comprender a los Estados Unidos y lic l's eran contemporáneos.

Se trata de una narración agradable en la que el autor incluye descripciones del país y del pueblo estadunidenses en periodos diferentes. Dedica bastante espacio a algunas personalidades como 
George Washington y Woodrow Wilson, al proceso socioeconómico, a las relaciones con Canadá y Gran Bretaña, a la guerra civil y a las cuatro décadas que precedieron el ingreso de los Estados Unidos a la primera guerra mundial. Caracteriza a la sociedad norteamericana por su unidad, aunque no por ello deja de reconocer la existencia de conflictos internos. Morison incorpora, al final de la obra, una selección de la abundante bibliografía existente sobre la historia de los Estados Unidos e incluye mapas.

ARSA

COLMEX 38. Morison, Samuel Eliot y Henry Steele Commager, His-

973

M861h

BNAL

973

MOR.h

UNAM

E178

M585 toria de los Estados Unidos de Norteamérica, México, FCE, 1951, 3 vols. (Sección de Obras de Historia).

La primera edición en inglés de esta obra (The Growth of the American Republic) fue publicada en 1930 en un solo volumen, mientras que la primera versión en español es de 1951 , consta de tres tomos y corresponde a la cuarta edición en lengua inglesa. Comprende desde los origenes del hombre en América hasta la elección presidencial norteamericana de 1948.

Ambos autores dirigen su libro expresamente a los "jóvenes de cualquier edad, a quienes no es necesario ni adecuado andar dosificando la verdad" (del prefacio). El texto se fundamenta en el hecho de que la historia comprende el conjunto de las actividades de un pueblo: económicas, sociales, literarias, espirituales, políticas y militares. Su objetivo central es mostrar una historia del crecimiento y los cambios de la civilización en el proceso de expansión de los Estados Unidos, desde una perspectiva que pretende resaltar el consenso del conjunto social

Obra que, dedicada a los veteranos de la guerra mundial, ofrece una visión amplia aunque oficial del devenir histórico del pueblo norteamericano, en una narración amena. Contiene mapas, notas a pie de página, anexo bibliográfico por capítulos, cuadros estadísticos y gráficas.

SNG

COlmeX 39. Morison, Samuel Eliot y Henry Steele Commager, The 973 Growth of the American Republic, 5a. ed., Nueva York, Oxford University Press. 1962. 2 vols.

$\begin{array}{ll}\text { UNAM } & \text { El libro, escrito por primera vez en 1930 (véase núm. 38), } \\ \text { E178 } & \text { fue modificado en varias ocasiones: 1936-1937, 1942, 1950. }\end{array}$

M58 Para esta edición, no sólo se escribió de nuevo enteramente,

UiA sino que se amplió hasta las elecciones presidenciales de

E178 1960. Se incluyeron también nuevos temas, por ejemplo los

M85g que se refieren a los negros y al sur entre 1865 y 1890 , a la mente norteamericana durante los años de la Reconstrucción o al poder mundial en la edad nuclear.

En cuanto a los autores de la obra, Samuel E. Morison es responsable del volumen primero, excepto de los capítulos sobre la guerra civil, y responsable de los correspondientes a la segunda guerra mundial en el volumen segundo. A su vez, Henry S. Commager es responsable del resto del volumen dos y de los capítulos sobre el conflicto de secesión en el primer volumen. 
Los dos historiadores piensan que la economía no basta para explicar la verdad de los hechos, sino que la historia debe abarcar toda actividad humana, ya sea económica o social, literaria o espiritual, política o militar. Tratan, por lo tanto, de acentuar esos aspectos y de lograr que su historia sea la de una civilización que crece y cambia dentro de unos Estados Unidos que se expanden. Ratifican sus ideas al dedicar el libro a las nuevas generaciones, las cuales, esperan, continuarán el desarrollo de la república norteamericana.

El texto incluye una completa enumeración de fuentes bibliográficas, un índice onomástico, varios cuadros estadísticos y mapas.

ARSA

BNAL 40. Vicuña, Pedro Félix, Los Estados Unidos, 2a. ed., Bue973 nos Aires, Saber Vivir, 1944, 389 p.

VIC.e Prologada por Agustin Edwards y fechada originalmente en 1931, el autor, chileno, se acoge a la visión de la historia en la que el desarrollo "natural" es el origen y causa de la: historia de Norteamérica, dirigida, sin embargo, por las grandes personalidades vencedoras en esa "contienda natural". Su tesis podría ser: "no hay nada torcido ni abusivo en el escalamiento del poder financiero. Es sólo fruto natural de la expansión de fuerzas naturales".

Según el prologuista, se trata de la primera obra sobre la historia de los Estados Unidos escrita en castellano. Intenta instruir con desapasionamiento a sus lectores acerca de los origenes democráticos del pueblo estadunidense, revelando "una admiración inteligente, serena, ordenada, fruto de la investigación y el estudio, que asoma a través de la relación que hace de los acontecimientos desde la llegada de los primeros colonos de origen puritano hasta el momento en que los Estados Unidos de América toman en sus manos el cetro económico y financiero del mundo civilizado".

Dentro del espíritu de la doctrina Monroe y creyente el escritor de ese panamericanismo, la narración transcurre desde los orígenes coloniales hasta la década de la administración Harding (1920 ss.), sin decir por ello que sigue una periodización precisa. No contiene bibliografía.

GZP

BBF

$\mathrm{S}$

973

ADA
41. Adams, James Truslow, La epopeya de 'América, 2a. ed., Buenos Aires, Claridad, 1943, 523 p. (Biblioteca de Obras Famosas, 87).

Con la pretensión de esbozar a grandes rasgas el pluriforme pasado histórico estadunidense, Adams intenta descubrir para sí mismo y para los estadunidenses el origen de su pueblo, con el propósito de explicarse el porqué de su carácter.

Editado por primera vez en 1941, el texto párte del supuesto apriorístico que sostiene que el ciudadano común estadunidense está plenamente consciente del "excepcionalismo" histórico de su país, lo cual hace que la obra carezca de objetividad, situación que se refleja desde su título. Se manejan conceptos tales como la "esperanza", "el sueño de una vida mejor, más rica y más feliz", expuestos como la mayor contribución del pueblo de los Estados Unidos al pensamiento de la humanidad. Siendo un trabajo esencial- 
mente descriptivo, está realizado en un lenguaje sencillo y ameno que asemeja la redacción de las novelas de caballería.

El marco temporal de la obra comprende desde el $x v$ hasta la tercera década del siglo $\mathrm{xx}$ para finalizar con un interesante epílogo que llama a los estadunidenses a salvar su democracia del peligro constante que representa la sociedad de consumo. Contiene índice onomástico y diversas ilustraciones. Carece de aparato crítico.

SNG

COLMeX 42. Craven, Avery Odelle, Democracy in American Life. A 973 Historical View, 2a. ed., Chicago, The University of ChicaC898d go Press, 1942, 149 p.

El texto se elabora a partir de la recopilación de cuatro conferencias que sobre el concepto de democracia en los Estados Unidos impartió el autor a los estudiantes de la Universidad de Chicago. Su objetivo central es el de contribuir al entendimiento de la vida contemporánea norteamericana a partir del estudio de "su democracia" reflejada a lo largo del pasado, de sus ideales, valores, instituciones, necesidades y su perspectiva futura.

Los capítulos del contenido de la obra son los siguientes: Thomas Jefferson y el dogma democráctico; El oeste y la democracia; La democracia y la guerra civil; La democracia y el capitalismo industrial. Incluye un indice temático-onomástico y su primera edición data de 1941. Carece de aparato critico.

MEL-ARSA

BBF 43. Nevins, Allan y Henry Steele Commager, Historia de S los Estados Unidos. Biografía de un pueblo libre, 7a. ed., MéNEV xico, Compañía General de Ediciones, 1974, 592 p.

Escrita en 1942 con el titulo de The pocket history of the BNAL United States. The story of a free people, esta obra ha sido 973
NEV.b revisada y actualizada en numerosas ocasiones.
Los autores parten de la idea de que la historia norteamericana, a pesar de su brevedad, es una de las más interesantes, pues "resume la historia de la especie [humana]", ya que los Estados Unidos de América han sido protagonistas de "las grandes fuerzas y factores históricos que han moldeado el mundo moderno". Los estadunidenses - según Nevins y Commager - tuvieron desde el principio conciencia clara de su "destino peculiar": la historia que nos presentan es, por tanto, el relato de cómo, a lo largo de cuatrocientos años, los norteamericanos han sabido cumplir ese destino reafirmando las esperanzas humanas depositadas en ellos.

El libro reviste singular interés, pues es una de las obras de mayor divulgación entre los lectores mexicanos. Abarca desde el establecimiento de las colonias en 1607, hasta el triunfo de Lyndon B. Johnson en las elecciones de 1964. Contiene bibliografía, indice onomástico y mapas.

MTB

COLMEX 44. Benet, Stephen Vicent, Historia sucinta de los Estados 
FLUNAM Escrita y editada por primera vez durante la segunda gueE178 rram mundial, esta obra lleva un mensaje patriótico - al B43 mismo tiempo que subjetivo y superficial - a un público geBNAL neral. Su autor define a los Estados Unidos como "un país 082.1 de esperanza, [...] de libertad", que no desea gobernar al AUS. C.1250 mundo o instaurar un imperio. Describe a sus habitantes como defensores de una sola causa: la de la democracia, y a sus soldados como intérpretes de su espiritu, al cual sirven. Pretende exponer, a través de sus quince capítulos, cuál es el significado de Norteamérica "como fuerza viva en el mundo". Con rasgos típicamente consensuales, Benet asegura que aunque los Estados Unidos no han solucionado todos sus problemas y han cometido errores, tanto internos como externos, su meta es construir un futuro en el que toda la humanidad goce de "pan y trabajo, (de) seguridad y libertad..." (p. 9-12).

La obra, titulada originalmente America, abarca desde los asentamientos ingleses en Virginia y Massachusetts a principios del siglo XVII, hasta la emisión de la Carta del Atlántico en 1941. Carece de aparato crítico.

MEL-ARSA

Colmex 45. Maurois, André, Historia de los Estados Unidos, Bue973

$\mathrm{M} 457 \mathrm{~h}$ nos Aires, Losada, 1943, 2 vols.

Libro de divulgación dirigido a un público amplio.

Escrita en estilo agradable, la obra tiene más características de novela que de un estudio histórico. Sus descripciones muy detalladas pretenden presentarnos paisajes de la historia norteamericana, sin que con ello consiga explicar o analizar los proceso sociales, económicos o políticos. Se presenta la historia de los Estados Unidos como resultado de acciones personales, de "pasiones y locuras humanas" que, en ocasiones, rayan en la cursilería y la frivolidad.

Producto de un enfoque conservador, la obra identifica lo popular con lo demagógico y es incapaz de presentar objetivamente los efectos del imperialismo sobre los países dominados. Abarca desde el descubrimiento de América (1492), hasta la entrada de los Estados Unidos a la segunda guerra mundial (1941). Contiene bibliografía. Titulada originalmente Histoire des Etats-Unis, la traducción al español no señala la fecha de la primera edición.

COLMEX 46. Casner, Mabel B. y Ralph H. Gabriel, The Story of 973 American Democracy, Nueva York, Chicago, Harcourt, C338S Brace, 1944, 632 p.

Obra dirigida a estudiantes norteamericanos de educación media, que exalta el valor de los grandes personajes de la historia nacional y su esfuerzo por establecer una sociedad democrática.

Lọs autores mencionan que sólo en términos de ideales y principios democráticos pueden ser entendidas todas las implicaciones sociales, económicas y culturales que integran el proceso histórico de los Estados Unidos. Sin embargo, la obra carece de análisis crítico. Con una serie de historias dramáticas tiene por objetivo llegar a la sensibilidad del lector. Siendo su preten- 
sión reforzar ideológicamente al estudiante, responde a las necesides de un momento histórico específico, la segunda guerra mundial, misma que se define como "el periodo en que los Estados Unidos eran atacados por sus más poderosos adversarios"(p. V).

Incluye una serie de caricaturas, fotografias e ilustraciones dignas de consideración. Además, contiene mapas, gráficas, bibliografía comentada y un anexo que complementan el espacio temporal de texto que va del siglo XIII a la cuarta década del siglo XX.

SNG

Colmex 47. Pérez Verdía, Benito Javier, Nociones de historia de los 973 Estados Unidos de América, México, SEP, 1944, 88 p. P438n (Biblioteca enciclopédica popular, 28).

BNAL Se trata de un resumen muy elemental de la historia de los 0821 Estados Unidos que forma parte de la tarea editorial de la SEP BEP.28 avilacamachista, orientada a "divulgar entre nuestro pueblo los valores más altos y auténticos del espiritu universal".

Sin ocultar su gran admiración por Norteamérica, el autor utiliza como guión de su texto "los hechos y dichos" de las crónicas presidenciales, y emplea para su redacción un estilo lleno de adjetivos cargados de emoción. Aunque hace alusiones al "problema mexicano", éstas parecen más bien estar descritas desde la misma perspectiva norteamericana. Bajo la óptica de la "política de la buena vecindad", Pérez Verdia cierra el libro con esta cita: "Hay quienes piensan que el mundo descansa sobre la fuerza. Mas aquí, en este continente, podemos afirmar que no es así. Y el curso de la hiștoria demuestra que a la postre el triunfo mayor es siempre el de las ideas nobles y las fuerzas espirituales" (p. 88).

El libro, que carece de aparato crítico, abarca desde el descubrimiento de América hasta la época del "New Deal".

BNAL 48. Roz, Firmin, Historia de los Estados Unidos, Madrid, 973

ROZ.h Plus-Ultra, 1944, 477 p.

El autor, miembro del Instituto de Francia, se propone mostrar al mundo la mayor de las lecciones de la historia norteamericana: la democracia. No escatima adjetivos para dejar ver su grandeza. Desde esta perspectiva trata de sacar enseñanza para su pueblo, Francia, en vísperas de la segunda guerra mundial. Sin ahondar en el capítulo preliminar sobre el descubrimiento y la colonización (1492-1763), el autor divide la obra en tres grandes periodos: la independencia, la unidad nacional y la expansión y solidaridad internacional. Considera que la etapa formativa de la nación norteamericana concluye con la guerra de secesión (1867), para rematar con el gran apartado sobre Estados Unidos como potencia mundial, al que dedica un mayor número de páginas.

El texto va acompañado de fotografías, además de una nota bibliográfica y un indice onomástico.

COLMEX 49. Hicks, John Donald y George E. Mowry, A short his973 H63is tory of American Democracy, 2a. ed., Boston, Houghton Mifflin, 1956, 864 p. 
Escrito en los años de la guerra fría, el libro pretende reafirmar los valores del sistema capitalista en su versión norteamericana. La obra - publicada por primera vez en 1946- obedece a la necesidad de sustentar en la historia de los Estados Unidos de América las raíces de los valores del liberalismo (derecho a la propiedad, a la felicidad, a la libertad, a la vida y la convicción de que el Estado existe para el individuo y no el individuo para el Estado).

Texto descriptivo, está dirigido a estudiantes preuniversitarios. Abarca desde lo que el autor llama "los origenes de la sociedad americana" (1607), hasta los años de la guerra fría (1955 ss.). Cuenta con mapas e ilustraciones y presenta, al final de cada capitulo, una selección bibliográfica.

MTB

BIM

973

BUT.a

50. Butterfield, Roger, The American past. A history of the United States from Concord to the Great Society. Nueva York, Simon and Schuster, 1976, 544 p. (A Fireside Book).

Destinado al público en general, este libro es editado por primera vez en 1947. Publicado de nuevo en 1957 y 1966 , aparece por cuarta vez en 1976 con motivo del bicentenario de la Declaración de Independencia de los Estados Unidos. En esta ocasión, con fe en su país y confianza en el porvenir, el autor señala que él también celebra un nuevo comienzo en los asuntos norteamericanos, después de "una década de división, derrota y oprobio". Considera que hechos como la

guerra de Vietnam o el escándalo de Watergate se pueden explicar como resultado del conflicto entre los dos poderosos impulsos que han caracterizado a la historia estadunidense: "el deseo de ser libre y de ver a otros hombres libres, y el deseo de ser más fuerte, más rico y más influyente que cualquiera" (del preámbulo).

Con énfasis en la política, a la que define como la historia "en marcha", y en la acción de los individuos, Butterfield elabora una historia superficial y anecdótica, tradicional, con tintes humorísticos. La completa con algunos documentos y un número considerable de ilustraciones - tomadas de fotografías, pinturas, caricaturas, dibujos, etcétera.

La obra se inicia con la batalla de Concord, Massachusetts (1775) durante la guerra por la independencia de los Estados Unidos, y termina con los primeros meses del gobierno de Lyndon B. Johnson (19631964). Cuenta al final con un índice onomástico, pero carece de aparato crítico.

MEL-ARSA

COLMEX

973

C898u
51. Craven, Avery Odelle, The United States. Experiment in Democracy, Boston, Ginn, 1947, 886 p.

El libro está dividido en tres grandes periodos: el colonial, que refiere el origen formativo de la nación norteamericana; el nacional, que centra su atención en la expansión hacia el oeste y la consolidación de la personalidad histórica de los Estados Unidos y el periodo de integración internacional, que corresponde al desarrollo del imperialismo. El autor sostiene firmemente la concepción del "excepcionalismo histórico" norteamericano. Los Estados Unidos aparecen como producto de la mezcla de muchas nacionalidades 
entre las cuales se destaca la participación de los europeos occidentales; el papel del azar se maneja como condición connatural de su proceso histórico.

Craven es un exponente de la corriente historiográfica del consenso, ya que niega la importancia de los conflictos del pasado y afirma la trascendencia histórica de la expansión hacia el oeste como fuerza determinante en la creación de las instituciones de su país. Los estadunidenses, según el autor, son claros exponentes de la "fe en el progreso" (p. XIX), la igualdad, el idealismo y el cambio, asi como producto de una sociedad de grandes oportunidades; en síntesis, de un "experimento democrático". El texto destaca el aspecto social.

Es una obra condensada, basada en la descripción histórica, que va del siglo XV hasta la cuarta década del siglo XX. Contiene mapas, ilustraciones, fotografías, bibliografía por capítulo e índice onomástico.

SNG

COLMEX 52. Mitchell, Broadies, La aventura norteamericana, Méxi973

M681a co, Intercontinental, 1949, $132 \mathrm{p}$.

Dirigido al público en general, el libro es de lectura fácil y agradable. Fue publicado en los Estados Unidos poco antes que en México con el título de American Adventure. El autor define al pueblo norteamericano como un pueblo fuerte y valiente que tuvo que luchar contra lo desconocido. Describe sus triunfos y narra sus penalidades en los días de la pesca de la ballena, de los cazadores y traficantes de pieles, de la lucha por el oro californiano, del ferrocarril subterráneo, etcétera.

Mitchell señala que los pobladores de los Estados Unidos, procedentes de los viejos países del mundo dotados de fuerzas y habilidades, llevaron a cabo la aventura norteamericana y formaron una nueva nación. Concluye que, después de las dos guerras mundiales que destruyeron las civilizaciones madres, sus hijos se han mostrado dispuestos a devolverles algo de lo recibido, a darles "una oportunidad, más la libertad... para reconstruirlo todo de acuerdo con sus ideas y deseos" (p. 132), a emprender una aventura norteamericana nueva. Carece de aparato crítico.

ARSA

Colmex 53. Rae, John B. y Thomas H. D. Mahoney, The United $973 \quad$ States in world history, from its beginnings to world leaderR134u ship, 3a. ed,, Nueva York, McGraw-Hill, 1964, 864 p.

UNAM La historia de los Estados Unidos es presentada como E178.1 parte de la civilización occidental, dando importancia a sus R26 aportaciones técnico-industriales. Sólo entre líneas se vis1964 lumbra la aplicación crítica de categorías al desarrollo histórico de un país que surge a la historia en la época del capitalismo moderno y del imperialismo.

Editada originalmente en 1949 , viene a llenar probablemente la necesidad de reformulación ideológica de Estados Unidos al erigirse como potencia mundial. Asi una pregunta fundamental da coherencia a las once partes de que se compone el texto: ¿cómo es que Norteamérica se convirtió en potencia mundial? Ante los hechos consumados - exterminio de los indios, esclavitud, guerras, impe- 
rialismo - los autores apelan al establecimiento de un nuevo consenso ante el futuro cargado de peligros, como la posibilidad de un desastre nuclear. A parte de acudir a la fe de los primeros colonizadores, su esperanza está puesta en la gran capacidad técnica y de adaptación a los cambios - "nuevas fronteras"- que ha mostrado el pueblo norteamericano a través de su historia. No olvidan destacar tampoco que Europa y los Estados Unidos son socios naturales de esta empresa de la civilización occidental.

El texto, que se extiende desde los antecedentes europeos del descubrimiento de América hasta el gobierno de John F. Kennedy (19611963), va acompañado de diversas ilustraciones y mapas, así como de una bibliografia seleccionada para cada una de las partes y al final, un indice temático-onomástico.

GZP

UIA

E178.2

54. Embajada de E.U.A., Pequeña historia de un pueblo hermano, s.p.i., 1950,47 p.

E5 Con estilo nacionalista, patriotero, este panfleto intenta dar a conocer a los mexicanos a sus "hermanos mayores del norte" - de cómo han llegado a ser lo que son, de cómo transgredieron fronteras, conquistaron la libertad, se industrializaron sin descuidar las ciencias y las artes-, a fin de que aprendan el ejemplo de los forjadores de esta "patria grande y respetada".

En forma bastante esquemática, el relato abarca desde el descubrimiento de América, la fundación y vida de las colonias, la independencia, la nación, la expansión territorial, la guerra civil, la industrialización, hasta el fin de la segunda guerra mundial, cuando los Estados Unidos se erigen como bastión de "la democracia". No contiene notas ni bibliografía alguna.

BBF

973

TOD
55. Todd, Lewis Paul y Merle Curti, Rise of the American Nation, 3a. ed., Nueva York, Harcourt Brace Jovanovich, 1972, $911 \mathrm{p}$.

Este libro, publicado originalmente en 1950 y actualizado en las ediciones sucesivas, introduce una nueva modalidad en el estudio de la historia de Estados Unidos al crear un apartado al final de cada unidad, dedicado al estudio de la relación entre la historia y alguna de las ciencias sociales en torno a un evento histórico especifico. Por ejemplo, el primer "caso" tratado con un enfoque sociológico es el de la comunidad puritana. Más adelante ve el concepto de la frontera desde el punto de vista geogrăfico. En el desarrollo del industrialismo el "caso" estudiado con una visión económica es el de la plata. En la unidad que va de 1898 a 1920 estudia antropológicamente a los grecoamericanos.

En cuanto a los temas, este texto de high-school parece estar dentro de la corriente liberal del consenso, pues escribe acerca de la lucha obrera para organizarse, la rebelión de los granjeros en contra de las prácticas de los grandes empresarios y da gran importancia al "Nuevo Trato" de Franklin D. Roosevelt. Lo que lo mantiene dentro del consenso es su fe en la gran capacidad histórica del pueblo norteamericano para superar los desafios. 
Contiene mapas, gráficas, un atlas histórico, una cronología, un índice onomástico y una lista de los documentos básicos en la historia de los Estados Unidos.

AMP

COLMEX 56. Baldwin, Leland Dewit, The Stream of American His-

973

B181s

tory, Nueva York, American Book, 1952, 2 vols.

El autor del texto examina los dilemas de la historia nor-

UNAM

E178 teamericana y la forma en que el pueblo los ha enfrentado o

B 18 evadido. Baldwin centra su atención en el papel del historiador como transmisor y organizador de los acontecimientos

BBF

973 del pasado, cuyo objetivo sería dar a conocer el significado del desarrollo de la humanidad, para propiciar el consenso de la sociedad.

La interpretación de la obra gira en torno a 3 factores básicos: la obligación moral y cultural de su autor de transmitir la "verdad" (p. vil), la certidumbre en la democracia y la creencia en la unidad de la historia.

El texto introduce en debates historiográficos sobre la objetividad y neutralidad de la historia. Baldwin analiza las contradicciones y conflictos del proceso histórico de los Estados Unidos, considerándolo como parte integral de la dinámica de la historia de toda la humanidad. Está dirigido a estudiantes preuniversitarios y abarca del siglo XV a la quinta década del siglo XX. Compuesto por 2 tomos, incluye mapas, ilustraciones, bibliografía general e índice onomástico.

SNG

UIA 57. Carman, Harry J. y Harold C. Syrett, $A$ History of the

E178 American People, 2a. ed., Nueva York, A. Knopf, 1954,

C27

BNAL Ambos autores, profesores de la Universidad de Colum-

973 bia, intentan presentar una historia objetiva de los Estados

CARM.h. Unidos basada en la realización de un esfuerzo evaluativo para juzgar "los acontecimientos del pasado a la luz de su propio contexto, evitando la imposición de esquemas históricos del presente" (del prefacio).

La interpretación del libro hace énfasis en la necesidad de dar a cada hecho histórico la significación que le corresponde, partiendo de una concepción positivista. Considerando que cada acontecimiento histórico es único, el texto se ha dividido cronológica y temáticamente con el objeto de reafirmar el conocimiento del lector sobre los aspectos políticos, diplomáticos, sociales, económicos, religioso - e intelectuales del devenir del pueblo norteamericano.

Editada por primera vez en 1952, la obra es de gran extensión y abarca del siglo $X V$ a la primera mitad del siglo XX. Contiene mapas, ilustraciones, cuadros estadísticos, apéndice documental y sugerencias bibliográficas que respaldan el análisis dirigido, de manera especial, a estudiantes norteamericanos preuniversitarios.

SNG

David S. Muzzey, conocido historiador y uno de los 
principales productores de libros escolares de historia norteamericana, realiza con éste uno dirigido expresamente a los nuevos inmigrantes hispanoparlantes, con el fin de ayudar en este caso a la "americanización" de los puertorriqueños. Con un estilo llano, simple, elemental, intenta adoctrinar además de aculturar; no sin razón comienza: "en nuestros dias, ser ciudadano americano significa formar parte del país más poderoso y afortunado del mundo" (p. 4).

El libro se divide en cinco partes que abarcan desde los fundamentos y fundación de la nación hasta la época contemporánea, o la del "mundo integral". Está ilustrado con mapas y fotografias en color y en blanco y negro con el fin de destacar la grandeza estadunidense.

Incluye bibliografía y un índice temático-onomástico, un apéndice documental con la Declaración de Independencia, la Constitución de los Estados Unidos y la de Puerto Rico como "Estado Libre Asociado", cuadros sinópticos y estadísticos sobre los estados, población, representantes políticos, territorios y dependencias en el exterior.

GZP

COLMEX 59. Parkes, Henry Bamford, The United States of America,

973

P245u

El autor se coloca dentro de la tradición progresista o de la "New History" de principios de siglo, que ve la necesidad de rescribir la historia desde las preocupaciones el presente, no sólo desde la perspectiva política, sino desde la sociedad en su conjunto. Aunque, en el marco de la guerra fria en el que se identifica al comunismo con el fascismo y el nazismo, estos autores progresistas toman el ropaje de los historiadores del consenso. Así, Parkes considera que frente a las grandes responsabilidades del presente, el estudio del pasado permitirá sacar la energía y la inspiración necesaria para afrontarlas.

La historia norteamericana es presentada como "única", ya que además de una forma de gobierno, ha creado un nuevo modo de vida. Dos factores la distinguen del resto de los pueblos: su conformación plural de etnias y culturas que, buscando libertad de oportunidades $-\sin$ incluir a los negros-, establecen instituciones democráticas, y la abundancia de tierras fértiles y recursos naturales que le permitió en poco tiempo alzarse como el bastión de la igualdad social, así como asumir el papel de líder mundial.

Dividido el texto en 24 capitulos, que abarcan desde los antecedentes europeos del descubrimiento de América hasta los años que siguen a la segunda guerra mundial, el autor intenta presentar los principales hechos de la vida política, discutiendo también el desarrollo económico y social, la vida intelectual y la expresión del espíritu norteamericano en la literatura y las artes.

El estilo de la presentación es convencional, casi enciclopédico. Incluye fotografias e ilustraciones, mapas, registros de población (17901950), presidentes, jefes de la suprema corte, elecciones, grados de educación, premios Nobel y una bibliografía detallada sobre los temas más variados, aparte de un índice onomástico. 
Se trata de una obra de claro contenido didáctico dirigida a estudiantes de secundaria con el propósito de infundir en los alumnos las ideas de que Norteamérica es la tierra de las grandes oportunidades (económicas, políticas y educativas), de la tolerancia racial (aunque en la fotografía que ilustra la idea sólo aparece un negro perdido en la multitud blanca), de la movilidad social, del respeto a los derechos y libertad de la mujer y de los individuos en general, cimentada sobre los principios de la reforma, más que de la revolución, y con una gran responsabilidad a nivel mundial.

Editado por primera vez en 1954 , el texto consta de 9 grandes apartados cuya entrada ya sugiere la noción de la historia norteamericana como un "experimento"; se cierra en el contexto de la guerra fría en "el desafio de la libertad" (década de 1950). Incluye en su presentación grandes espacios con fotografias, mapas, diagramas y caricaturas, cuestionarios para promover la discusión, además de indicaciones documentales y bibliográficas, en cada una de las partes. Al final se incluye un índice analítico.

GZP

UIA 61. Escher, hijo, Franklin, Breve historia de los Estados E178 Unidos, México, Guaranía, 1955, $172 \mathrm{p}$.

E74 Traducción de $A$ Brief History of the United States que se BNAL editó por primera vez en 1954. Se trata de una obra elemen973 tal con un propósito evidente de divulgación y como su títuESCG.b lo indica: breve. Historia descriptiva que tiende a simplificar los procesos históricos y a negar las contradicciones de COLMEX la sociedad norteamericana. Considera que "los Estados E74b Unidos se convirtieron en el campeón del hemisferio occidental y protector de los paises de América" (p. 78).

$\mathrm{Su}$ autor, influido por el ambiente triunfalista de la posguerra, afirma que los principios de la doctrina Monroe conservan su validez pues el pueblo norteamericano cree, ahora más que nunca, que su propia seguridad depende de su capacidad para resistir a la agresión hasta en los lugares más remotos del mundo (p. 79).

El libro - que carece de bibliografía - puede ser fácilmente sustituido por otro de mejor calidad si lo que se pretende es obtener información elemental o hacer un primer acercamiento a la historia de los Estados Unidos de América.

MTB

BBF 62. Harkness, hijo, Albert, Esbozo histórico de la cultura S norteamericana, 2a. ed., México, Embajada de los Esta973 dos Unidos de América, 1954, 72 p.

H282 Harkness lleva a cabo un esbozo del desenvolvimiento cultural norteamericano desde sus antecedentes puritanos, en los siglos XVI y XVII, hasta sus características en vísperas de la segunda guerra mundial. Sin embargo, no hace más que explicar las treinta y cuatro ilustraciones que acompañan al texto.

Dirigida al pueblo de México, publicada por la embajada de los Estados Unidos en este pais y al parecer escrita originalmente en español, la obra muestra la persistencia de ciertos rasgos a lo largo de la historia cultural estadunidense. Por ejemplo, la influencia 
de la Nueva Inglaterra puritana con su materialismo y pragmatismo, manifiesto en el carácter norteamericano -en sus actitudes y productos- muchas generaciones después. Reconoce, sin embargo, la existencia de cambios a través del tiempo. Tal es el caso de la influencia del Racionalismo en el siglo XVIII, cuando los intelectuales pasan de la mera especulación al culto por la adquisición del conocimiento, a través de la razón y la experimentación. La obra carece de aparato crítico y de fecha de primera edición.

ARSA

COLMEX 63. Baldwin, Leland Dewitt, The adult's American history: 973 pragmatic democracy in action, Rindge, Richard R. Smith, B181: $1955,786 \mathrm{p}$.

Baldwin revisa la historia de los Estados Unidos desde el siglo XVI hasta mediados del XX. La caracteriza como la de "una democracia pragmática en acción"; esto es que no es materialista ni idealista, sino que ha tratado de ser realista, y que no es todavía una estructura acabada sino un proceso que para tener éxito ha debido, y deberá, asentarse en el principio fundamental de la defensa de la dignidad y la libertad humanas. El autor trata de descubrir la manera en que esta "democracia pragmática en acción" ha influido en la conformación histórica de los Estados Unidos, en el desarrollo de su modelo de vida y en su conversión en un poder mundial.

Es interesante señalar la idea de Baldwin - caracteristica de la historiografía neoconservadora - de que su país tiene la misión de ofrecer al mundo tanto la democracia como la producción masiva, bases importantes para una mejor forma de vida. Y añade que si bien no existe una intención de obligarlo a aceptarlas, los estadunidenses creen en ellas tan firmemente que para protegerlas no se detendrán ante nada.

El libro consta de mapas, notas bibliográficas al terminar cada capítulo y, al final, de un apéndice documental y un índice onomástico.

ARSA

UNAM 64. Canu, Jean, Historia de los Estados Unidos, Barcelona, E178.1 Salvat, 1956, 152 p. (Colección Surco, 13).

C35 Jean Canu, de nacionalidad francesa, publicó esta obra en París en 1955 en el número 38 de la prestigiada colección "Que Sais-Je" de la editorial Presses Universitaires de France, con el título de Histoire des Etats-Unis. Se trata de una historia general de los Estados Unidos que, en pocas páginas, pretende cubrir un periodo que va desde el siglo XVI hasta mediados del XX.

El autor no deja de reconocer los méritos de la cultura norteamericana: el despertar de un continente desconocido, la valoración de sus prodigiosos recursos, el ininterrumpido crecimiento de su población, el desarrollo de una sociedad original... Sin embargo, algunos rasgos progresistas le llevan a señalar que "el coloso" tiene debilidades y el progreso automático ilusiones y que los esfuerzos de cada generación por mantener, primero la igualdad y luego el libre desarrollo de cada norteamericano, han sido vanos. Para concluir plantea la cuestión de si los estadunidenses serán capaces de dar a sus obreros una estabilidad y seguridad burguesas, al mismo tiempo que las gran- 
des companias se fortalecen y enriquecen. Tal vez por estar dirigida al público en general, la obra carece de fuentes bibliográficas.

ARSA

Flunam 65. Nye, Russel B. y J. E. Morpurgo, A history of the Uni-

$\mathrm{E} 178$

N93

1970 ted States, Harmondsworth, Penguin Books, 1970, 2 vols.

Editada por primera vez en 1955 , esta obra está dirigida a un público amplio y tiene la singularidad de haber sido escrita por un autor norteamericano y otro inglés, quienes al trabajar en conjunto pretenden neutralizar los prejuicios propios de una visión estadunidenses o británica.

Los autores sostienen que la historia norteamericana estuvo estrechamente ligada a Inglaterra por lo menos hasta el momento de la independencia y que las violentas relaciones de las coloniàs con la metrópoli, precipitaron en buena medida el proceso de "americanización".

Pretenden integrar la historia de los Estados Unidos a la historia mundial, así como estudiar el papel de la nación estadunidense en el curso del acontecer universal. Este texto, que sigue la mayoría de los procesos históricos desde la línea del consenso, no deja por tanto de tener la visión de los dominadores que ignoran los efectos del expansionismo sobre los pueblos.

La obra abarca desde el descubrimiento de América hasta la elección del presidente Richard Nixon. Presenta bibliogralïa, indice onomástico y mapas.

UIA 66. Bailey, Thomas A., The American Pageant. A history of E178.1 the Republic, Boston, Little Brown, 1956, $1008 \mathrm{p}$.

B15a Gran admirador de su patria, Bailey narra la historia de BNAL los Estados Unidos, pais que ve como "girgantesco y úni973.4-9 co" (p. VII), con el propósito de estimular el interés del BBF - pueblo estadunidense por ella. Como se propone escribir un 973 libro que pueda ser leido no sólo con placer sino también BAI con excitación, da relieve a los actores y énfasis al calor y al drama de la historia. De esta manera logrará - dice- la comprensión de los problemas que enfrentan los estadistas y provocará una inquietud más viva por las lecciones del pasado. Bailey concibe la historia de los Estados Unidos como un ancho rio que fluye continuamente hacia adelante, en el cual la corriente politica es la más definida. Y, aunque presta gran atención a otros aspectos, el económico por ejemplo, lo político constituye en cierta forma una especie de guión.

El libro, que se extiende desde la llegada de Colón a América hasta la confrontación soviético-estadunidense después de la segunda guerra mundial, cuenta con cuadros ilustrativos, mapas y buenas sugerencias bibliográficas al final de cada capitulo. El texto se complementa con excelentes caricaturas publicadas en las diversas épocas que se estudian.

ARSA

COLMEX 67. Elson, Henry William, Estados Unidos de América, Bar- 
BNil. esta obra ha sido revisada, ampliada y reeditada en varias 973

I:I.S.e ocasiones. La versión en español se basa casi totalmente en

UNAM

$1: 45$ The History of the United States de 1956. Se extiende desde 1.5 el periodo de las exploraciones europeas en Norteamérica hasta la segunda guerra mundial (1939-1945).

La historia escrita por Elson está dirigida al público en general y es bastante descriptiva, sumamente detallada, carente de espíritu crítico y, al parecer, destinada a alabar las "glorias de la Gran República". Ubicable dentro de la corriente historiográfia del consenso, no penetra en el análisis de los procesos económicos o de la estructura de la sociedad. Pretende no olvidar los distintos aspectos de la vida cotidiana del pueblo estadunidense, pero destaca especialmente a la historia política, sobre todo a la que se desarrolla a partir de la independencia.

El autor presta especial atención al estilo literario, logrando un texto de ágil lectura. Presenta una selección bibliográfica al final de cada capitulo.

BNAL 68. Janssens, Jacques, Historia de los Estados Unidos, 1492$973^{\circ}$

IAN.h Síntesis muy apretada, de corte descriptivo, con una visión superficial de los hechos más importantes de la historia norteamericana. Hecha para el público común, su lectura es ágil y su narrativa sencilla.

El autor, de nacionalidad francesa, simpatiza con los Estados Unidos, país que ha sido aliado del suyo durante la segunda guerra mundial y la guerra fría. Piensa que la victoria estadunidense sobre la Unión Soviética significa el triunfo de la paz, la libertad, el progreso, la democracia, en fin, de la civilización. Aunque acepta la existencia de problemas dentro de la sociedad a la que tanto admira, considera que no son insuperables. Por ejemplo, la segregación racial paulatinamente atenuada y a la que muy . pronto - dice- se dará una solución definitiva, "conforme a la humanidad y la equidad" (p. 213).

Con el titulo de Petite histoire des Etats-Unis, la obra fue publicada por primera vez en 1956. Se extiende de 1492, año del descubrimiento de América, hasta los primeros años del gobierno de Dwight D. Eisenhower (1953-1955). La versión en español fue completada con los hechos ocurridos en la historia de los Estados Unidos entre 1956 y 1961.

El libro cuenta con ilustraciones, un mapa y al final, con una cronología somera. Carece de aparato crítico.

MEL-ARSA

Colmex 69. Miers, Earl Schenck et al., The American Story. The 973.082 M632a Age of Exploration to the Age of the Atom, introducción de Allan Nevins, Great Neck, Nueva York, Channel Press, 1956, 352 p.

Resultado del esfuerzo de sesenta historiadores norteamericanos, este libro consta de diversos estudios sobre la historia de los Estados Unidos que abarcan desde los años de la llegada de los vikingos a la América del Norte, hasta los de la guerra de Corea entre 1950 y 1953 . Su objetivo original fue de 
divulgación; transmitidos por radio desde la ciudad de Nueva York, millones de personas los escucharon.

Los autores, algunos progresistas, otros del consenso, son grandes admiradores de la historia norteamericana que consideran insuperable, tanto por su amplitud, variedad y color, como por su idealismo moral. Quieren ser veraces, despertar la imaginación y estimular la curiosidad de sus oyentes y lectores, proporcionar lecciones para el futuro y crear un fuerte sentido nacional, sin olvidar los sentimientos de fraternidad entre los hombres y de unidad dentro del mundo libre.

La obra supone que, a lo largo de la historia de los Estados Unidos, la democracia se ha perfeccionado, no sólo en un sentido político, sino también económico y social. Así se han eliminado diferencias raciales, de clases, educación y riqueza $\mathrm{y}$, aunque los inmensos cambios en la ciencia y la tecnologia han hecho que la nación tenga que enfrentar el urgente problema de la paz, también han permitido que vislumbre un futuro más brillante que el concebido por sus antepasados, tanto en bienestar económico como en crecimiento moral e intelectual. Cuenta con un índice onomástico e ilustraciones.

ARSA

COlmex 70. Espinosa, Miguel, Las Grandes Etapas de la Historia 973.01 Americana, Madrid, Revista de Occidente, 1957, 147 p.

E77g El autor de la obra incursiona en el análisis de las institu-

BNAL ciones, ideas y actitudes politicas de la sociedad estaduni973 sense, con el propósito de explicar su proceso histórico. La ESP.g obra posee carácter intelectual, pues se aboca al estudio de UNAM cuestiones políticas muy concretas como lo es el sentido de la E175.9 democracia estadunidense y su relación con el surgimiento E8 de un Estado nacional.

Resulta paradójico que, siendo Espinosa español, el texto aparezca durante la dictadura franquista afirmando que los Estados Unidos son resultado de un consenso social, fundamentado en la responsabilidad ciudadana, sustento a la vez de la democracia norteamericana. De manera general y sintética, la obra aborda un periodo que abarca de la colonización europea de América hasta la etapa rooseveltiana del "New Deal". El libro, prologado por el maestro Enrique Tierno Galván, contiene apéndice e índice de nombres y materias, pero carece de aparato crítico.

SNG

COLMEX 71. Gewehr, Wesley Marsh et al., American Civilization: $a$ 973 history of the United States, Nueva York, McGraw Hill G396a Book, 1957, 588 p.

UIA Ante la necesidad de un libro de texto que establezca las E176.1 líneas generales de la historia de los Estados Unidos sin caer G4 en detalles de nombres y fechas ya familiares a los estudian-

FLUNAM tes universitarios, los historiadores responsables de esta E 778.1 obra explican en especial las tendencias, los significados y G49 las interpretaciones históricas.

Definen la historia de su país como de cambio, pero reconocen la continuidad de la organización sociopolítica democrática o de la idea básica de que cualquier ser humano tiene derecho a participar en las "cosas buenas de la vida". Piensan que la "socie- 
dad sin clases" es ya casi una realidad dentro del capitalismo estadunidense, aunque aceptan que alcanzarla significó una lucha y que aún existen problemas como la discriminación racial. Añaden que si bien el mundo no ha asumido siempre su modelo de vida, los Estados Unidos han tenido y tienen todavia la misión de llevarle la democracia. No se trata de "norteamericanizarlo", sino de aprovechar su influencia y resolver en conjunto los problemas.

Aunque conserva tintes progresistas, el libro participa en las tendencias historiográficas reinantes en los Estados Unidos después de la segunda guerra mundial. Se extiende desde los antecedentes europeos y coloniales de la historia estadunidense hasta el triunfo de Dwight E. Eisenhower en las elecciones de 1956. Cuenta con breves cronologías y sugerencias bibliográficas al principio y al final, respectivamente, de cada capítulo. Tiene también apéndice documental, estadísticas e índice onomástico, además de ilustraciones y mapas.

ARSA

COLMtx 72. Savelle, Max, Historia de la civilización norteamericana, 917.3

$526,3 \mathrm{~h}$

FLUNAM El96.1 S3

Madrid, Gredos, 1962, 599 p.

Traducción de la obra norteamericana escrita en 1957 y titulada $A$ Short History of American Civilization.

El libro está destinado a cursos universitarios de historia de la civilización norteamericana aunque espera ser de interés y utilidad para cualquier clase de público.

Es una historia de civilización norteamericana que intenta enfocar como fenómeno unitario y presentar su desarrollo en estrecha relación con la economía, la sociedad, los aspectos intelectuales, religiosos y estéticos, integrando todos estos elementos al desarrollo histórico. Se busca así presentar la civilización estadunidense como una totalidad. Considera que ésta ha pasado por seis fases en torno a las cuales se desenvuelve la obra: primera, nuevas sociedades inglesas en la comunidad atlántica; segunda, las bases de la nueva nación; tercera, el logro de la Independencia; cuarta, división e integración; quinta, metamorfosis: la industrialización de la vida norteamericana; sexta culminación: democracia en América y en el mundo.

Presenta una bibliografía breve en cada fase y contiene mapas, ilustraciones e indice onomástico.

MTB

COLMEX 73. Boorstin, Daniel J., Historia de los norteamericanos. La 917.303 experiencia colonial, 4a. ed., Buenos Aires, Tipográfica EdiB724h torial Argentina, 1973, $483 \mathrm{p}$.

v.l Traducción de The Americans. The colonial experience

BBF (editada por primera vez en 1958) esta obra se completa con $S \quad$ otras dos: The Americans. The national experience y The 917.3 Americans. The Democratic experience, escritas en 1965 y BOO 1973 respectivamente (véase núm. 93 y 96).

Boorstin, connotado representante de la corriente neoconservadora, plantea en este trabajo muchas de sus tesis fundamentales. Afirma que en Norteamérica no se retomaron las concepciones de sociedades utópicas, las teorias políticas, las distinciones de clase europeas. Los estadunidenses - dice- se ocupa- 
ron de situaciones y problemas concretos surgidos del medio al que tuvieron que enfrentarse y fue esta condición la que moldeó su carácter práctico. En él periodo colonial, los puritanos de Nueva Inglaterra encarnan ese pragmatismo; se convierten asi - según señala - en el símbolo de la historia del pueblo estadunidense al tiempo que marcan el principio de la tradición práctica estadunidense, persistente durante todas las épocas.

El libro, de interés para público especialiżado, trata del periodo colonial, desde la llegada de los peregrinos del "Mayflower" a Plymouth (1620) hasta los años anteriores al comienzo de la guerra de independencia (ca.1775). Carece de aparato crítico y de bibliografía:

MTB

Colmex 74. Rémond, René, Histoire des Etats-Unis, París, Presses Q82.1 Universitaires de France, 1959.127 p. (Que Sais-Je?, 38).

v.38

Es el mismo texto correspondiente a la Histoire Universelle, núm. 3 de la Encyclopédie de la Pléiade, París, Gallimard, 1958, p. 967-1058.

La historia de los Estados Unidos, al parecer, impresiona a muchos observadores europeos, pues encuentran dos aspectos de los que ellos carecen: la movilidad y el constante progreso económico dentro de una gran estabilidad constitucional. Así, en la línea de la tesis del "excepcionalismo" estadunidense el autor va a presentar el espectáculo del nacimiento de una nación de orígenes modestos, pero que corre con la suerte de insertarse de lleno en el nacimiento del mundo moderno; es decir, sin tener que contar con los lastres de la tradición feudal. De modo que así le fue posible pasar rápidamente del entorno provincial al metropolitano. La lucha de clases toma en Estados Unidos la forma de lucha del hombre, del individuo, contra la naturaleza.

Inicia la sintesis con la fundación y desarrollo de las colonias, para detenerse luego en la época constitucional, vincula el nacimiento de la nueva sociedad con la expansión hacia el oeste, da importancia al movimiento populista que le sigue al fin de la guerra civil, terminando con el desarrollo de la industria y los cambios sociales que conlleva y que implican el cambio de la política exterior de la neutralidad al imperialismo.

El autor no oculta que dentro de la bibliografía consultada en lengua francesa, una de las mejores historias que leyó fue la proporcionada por el Servicio Norteamericano de Información (Frances Friedman, Esquisse d'une histoire des Etats-Unis d'Amérique).

GZP

COLmex 75. Degler, Carl N., Out of our past. The Forces That Sha973 ped Modern America, 2a. ed., Nueva York, Harper ColoD310ou phon Books, 1970,546 p.

Obra dirigida a conocedores. Trata temas no incluidos tradicionalmente en las historias descriptivas, como la historia de los negros, la influencia de la ciudad, los orígenes de la nacionalidad estadunidense.

El propósito del libro, publicado por primera vez en 1959, es "buscar una respuesta a la interrogante de ¿cómo lograron los [norte] americanos llegar a ser lo que son a me- 
diados del siglo $x \times$ ?" (p. XIII). La solución se refiere a los rasgos peculiares o "privilegiados" del desarrollo histórico estadunidense.

El libro que no sigue las pautas de una historia descriptiva, presenta temas relevantes a lo largo de la historia de los Estados Unidos, desde la llegada de los europeos a Norteamérica hasta el momento del enfrentamiento con la Unión Soviética, después de la segunda guerra mundial. Incluye bibliografía comentada especializada.

MTB

BBF $S$

973 $\mathrm{JOH}$

76. Johnson, Gerald W., Siglo XV a siglo XvIII: amanecer de un coloso, Buenos Aires, Plaza\& Janés, 1966, 2 vols.

Con el título original de America is born. A history for Peter (1959), este texto se complementa con otro titulado Siglo XVIII a siglo XX: una pujante promesa (America grows up. A history for Peter, 1960).

Salta a la vista inmediantemente que esta especie de manual carece de prólogo, índice y toda clase de aparato crítico. Escrito en estilo muy elemental, a veces un tanto cursi, el relato está lleno de simplificaciones y lugares comunes.

El primer volumen parte del descubrimiento de América y termina con la etapa colonial (cap. I-VII) y el segundo va de la revolución de independencia hasta la declaración de guerra de Wilson, durante la primera guerra mundial (cap.I-XI).

GZP

BBF

.973

SME
77. Smelser, Marshall y Joan R. Gundersen, American History at a Glance, 4a. ed., Nueva York, Harper and Row, 1978, $298 \mathrm{p}$.

Esta obra povee una visión sintética, clara y concisa de los principales acontecimientos y tendencias del proceso histórico norteamericano, con el objeto de difundir su conocimiento entre un público de adultos. La edición original data de 1959, mientras que la cuarta es una versión revisada y actualizada en su totalidad.

El énfasis del texto está dado en la relación económicopolítica, por lo que el aspecto social se trata únicamente como apéndice de dicha dicotomía. Aunque no se analiza con profundidad cada suceso, los autores del libro dejan ver la discontinuidad y complejidad históricas de las cuales surgen los Estados Unidos pero sin llegar a aceptar sus contradicciones fundamentales.

El libro, publicado en papel reciclado, abarca desde los orígenes expansionistas europeos de los siglos XIII y XIV, hasta las administraciones de Ford y Carter, en la séptima década del presente siglo. Contiene mapas e índice onomástico pero carece de a parato crítico.

SNG

COLMEX 78. Williams, Thomas Harry, Richard N. Current y Frank 973 W $727 \mathrm{~h}$ Freidel, A history of the United States, 4a. ed., Nueva York, Alfred A. Knopf, 1963, 2 vols.

Texto dirigido a estudiantes preuniversitarios que gozó

UIA E178.1 W 5 con certeza de una gran demanda entre los escolares (tuvo cinco reimpresiones entre 1959 -año de su primera edi- 
ción- y 1963). Comprende desde la colonización de Norteamérica hasta el periodo contemporíneo.

La presentación de los temas no abandona la lorma tradicional. Contiene igual que otras obras de esta indole, mapas, ilustraciones, sugerencias bibliográficas y un apéndice documental. Todo ello junto a un relato muy pormenorizado de la historia de los Estados Unidos.

Su discurso se aboca no sólo a justificar el curso de la historia norteamericana, sino a explicar su "excepcionalismo histórico", como resultado de fuerzas geográficas, culturales e históricas que ineludiblemente traspasan la voluntad humana. Explica el expansionismo de los Estados Unidos como un proceso semejante al de otras naciones europeas, surgido de la consideración de que sus instituciones eran mejores y por tanto les asistía el derecho y obligación de imponerlas a pueblos "menos capaces o afortunados".

MTB

$\mathrm{BBF}$

973

79. Gavian, Ruth W. y William A. Hamon, United States

GAV

History, 2a.ed., Boston, D. C., Heath, 1965,915 p.

Escrito en 1960 y revisado en 1965, es un libro de texto para high-school que cubre desde el descubrimiento de América (1492) hasta la toma de posesión de Lyndon B. Johnson (1964). Cada capitulo termina con ejercicios planeados para lograr la asimilación de la materia expuesta. Al final de cada unidad se dan los puntos relevantes de cada época, una lista de preguntas sobre todo el material y otra de lecturas pertinentes. Esta última divide los libros sugeridos en tres: históricos, biográficos y novelas históricas o memorias. Cada una de la unidades va precedida por una "línea de tiempo" que da las fechas y los eventos más importantes de cada periodo. En el apéndice incluye una lista de presidentes y vicepresidentes, la Declaración de Independencia y la Constitución de los Estados Unidos. Contiene indice onomástico y mapas.

Está redactado en los términos usuales de la corriente neoconservadora: la colonización fue una epopeya realizada por gente que "no pertenecia al común de los mortales" y conformó una nueva nación consagrada a la libertad.

AMP

COLMEX 80. Malone, Dumas y Basil Rauch, Empire for Liberty. The 973 M257e Genesis and Growth of the United States of America, Nueva York, Appleton Century Crofts, 1960,2 vols.

Malone y Rauch "relatan" la historia norteamericana desde sus antecedentes europeos hasta el segundo gobierno del presidente Eisenhower (1957-1960). Tratan de cubrir todos los aspectos importantes: políticos, económicos, constitucionales, diplomáticos, sociales, religiosos, artísticos e intelectuales. Empero, los autores hacen énfasis en las relaciones internacionales, la ideología y las corrientes actuales del pensamiento. No olvidan, como ellos mismos señalan, que la historia es hecha por seres humanos, antes que por fuerzas impersonales.

El libro, dedicado por los autores a los estudiantes que fueron sus alumnos en diversas universidades, establece la "libertad individual" 
como su hilo conductor y el "Imperio de la Libertad" como la meta de los estadunidenses durante su historia. Consta de mapas muy claros y de una completa bibliografía.

ARSA

BNAL 973

PEY.e

81. Peyret, Henry, Los Estados Unidos, Madrid, Taurus, 1967, 283 p. (Colección: El mundo cambia).

Originalmente la obra fue publicada en francés por la editorial "Presses Universitaires de France" en 1961, con el título Les Etats Unis. Está inserta claramente en el contexto de la confrontación política, ideológica y militar entre las. dos potencias surgidas de la segunda guerra mundial. Siendo francés, y por lo tanto con cierta distancia critica, el autor no oculta su preferencia por los Estados Unidos. Basada en factores determinantes como la migración, la expansión territorial, las formas políticas constitucionales y el espíritu de empresa, esta obra permite adentrarse en algunos aspectos básicos del proceso histórico estadunidense, como serían la conformación de un estado capitalista y su política exterior.

Escrita con frases breves, a veces un tanto cortantes, este texto puede servir de introducción general a la historia estadunidense contemporánea, época en la que el autor concentra su atención.

El autor divide la obra en tres partes. La primera trata sobre los fundamentos de la historia estadunidense (vasto territorio, abundante migración, constitución adecuada y un sistema democrático-industrial); la segunda, versa sobre las relaciones entre el sistema económico y político, concentrándose en los siglos XIX y XX, y la tercera se centra en la política exterior, desde sus origenes hasta la guerra fría. Contiene al final una bibliografía sumaria.

GZP

BBF

$\mathrm{S}$

973

RIC

82. Richter, Werner, Breve historia de los Estados Unidos, Buenos Aires, "El Ateneo", 1962, 191 p.

Por medio de una narración atrayente, el autor alemán delinea la evolución histórica de los Estados Unidos, brindando una información objetiva y sintética.

Dirigido a la totalidad del público, este breve volumen se adapta a quien busca en su contenido una lectura estimulante. La exposición temática del libro aspira a esclarecer el porqué de los sucesos políticos que han perfilado la historia estadunidense, Richter no oculta su admiración a los logros alcanzados por los Estados Unidos, afirmando incluso la modestia de éstos para asumir la responsabilidad "universal" de oponerse a la Unión Soviética como fuerza equilibradora.

La primera edición del texto data de 1961, siendo su título original: Kleine Geschichte der Vereinigten Staaten. Abarca un espacio temporal que parte del establecimiento de las 13 colonias británicas en la costa Atlántica norteamericana (siglo XVIII), hasta la etapa de la guerra fría (mediados del siglo XX). Contiene una somera tabla cronológica, fotografías e ilustraciones, pero carece de aparato crítico. 
COLMEX 83. Eisenstadt, Abraham Seldin, ed., American History: 973.082 Recent Interpretations, Nueva York, Thomas Y. Crowell, E36a 1962, 2 vols.

Antologia de ensayos de varios historiadores de prestigio, representativos de los puntos de vista más novedosos sobre la historia de los Estados Unidos después de la segunda guerra mundial. Su objetivo fue proporcionar a los estudiantes universitarios una serie de textos que complementasen sus cursos de historia norteamericana, para que, a través de su lectura, conocieran otras opiniones acerca de los problemas, los procesos y los individuos tratados por los historiadores. Se destacá el desarrollo económico, social, religioso e intelectual.

Los diversos ensayos que se presentan proceden de reconocidas publicaciones periódicas. Cada uno cuenta con una introducción en la que se definen la naturaleza e importancia del tema presentado y sugieren preguntas acerca del mismo o del periodo tratado.

La obra se extiende desde los antecedentes indigenas y europeos de las colonias inglesas en América del Norte hasta las características de la sociedad estadunidense de mediados del siglo XX. Concluye con un texto de Arthur M. Schlesinger, en el que se alude a las diez contribuciones estadunidenses a la civilización ("América's Influence: Our Ten Contributions to Civilization"). Al final de cada uno de sus volúmenes cuenta con una bibliografía y un índice analítico.

MEL-ARSA

COLMEX 84. Blum, John M. et al., The national experience. A history 973

N277

1973

of the United States. Third edition, Nueva York, Harcourt Brace Jovanovich, 1973, 889 p.

Editada por primera vez en 1963, dirigida a estudiantes universitarios, la obra se propone explicar la experiencia histórica de los Estados Unidos: la realizada por cada una de sus generaciones de hombres y mujeres. Hace destacar en la política institucional, la cual - se indica- permite la introducción a la historia nacional y al conocimiento de su trama.

El texto por medio de Arthur M. Schlesinger hijo, uno de los coautores reconoce la existencia de confusión social y moral, de frustración, miedo y violencia en la sociedad estadunidense. Acepta, incluso, que los Estados Unidos han perdido influencia en el mundo. Mas, con un tono consensual, considera que todo ello se debe al acelerado desarrollo de la ciencia y la tecnología, no a la decadencia moral o a la corrupción del sistema económico. Manifiesta confianza en su país, en tanto que señala que si éste actúa con inteligencia, voluntad y dotes de mando evitará no sólo la desmoralización interna y la desintegración, sino también restaurará la influencia perdida, al ofrecer a otras naciones el ejemplo de cómo enfrentar las crisis propias de la modernidad.

Los autores se extienden desde el descubrimiento de América en 1492 hasta el primer gobierno de Richard M. Nixon (1969-1972). Incluyen mapas, ilustraciones y selecciones documentales que en ocasiones confrontan dos puntos de vista sobre el mismo tema y sugieren y comentan brevemente algunas lecturas al final de cada capitulo. Proporcionan, en sus últimas páginas, una bibliografía, cuadros estadisticos y un índice onomástico. 
COLMEX 85. Davis, Harold Eugene, Los Estados Unidos en la histo-

973

D262e

UIA

E175

D38

BNAL

082.1

UTEHA

m.353 ria, desarrollo histórico de su pueblo y su significación, México, Unión Tipográfica Editorial Hispanoamericana, 1967, $150 \mathrm{p}$.

El texto, que abarca de 1700 a 1930 , pretende señalar las experiencias comunes de la historia de los Estados Unidos y las demás naciones de América y funcionar como una obra imparcial dirigida expresamente a estudiantes universitarios no estadunidenses.

La historia del "Continente Americano" -valga la expresión puesto que ésta se ve reducida a la historia de los Estados Unidos - se presenta como parte integral de un proceso de cambio cultural que entraña la fusión de elementos europeos, indigenas y africanos. La obra se refiere también al pragmatismo de la sociedad estadunidense y trata de expresar lo que de universal hay en su experiencia histórica.

El autor considera al movimiento de independencia de su país como el movimiento revolucionario original, germen de todos los movimientos sociales posteriores, llegando a afirmar que tanto el fascismo como el comunismo son sus derivados abortivos.

El libro es tendencioso, pues su contenido incide de manera explícita en la conciencia de sus lectores. Por ello, es una obra "ideologizante", lo que hace que su alcance científico sea bastante discutible.

Contiene notas bibliográficas. El título original en inglés es The United States in History, Historical Experiences of her People and their Significance. Su primera edición fue hecha en 1963. .

SNG

COLMEX 86. Handlin, Oscar, The Americans; a new history of the 973 H236a people of the United States, Boston, Little, Brown, 1963, $434 \mathrm{p}$.

El autor, uno de los más conocidos historiadores de los Estados Unidos, describe la influencia de la inmigración en el surgimiento del pueblo norteamericano. Parte de la base de que el eje central de su historia lo compone el continuo proceso de colonización continental. Analiza los retos que han tenido que enfrentar los estadunidenses para moldear su sociedad dentro de un ámbito de progreso. Por encima de la individualidad de los sujetos, hace destacar la participación histórica del conjunto social y la importancia de sus fracasos como fuerza generadora de grandeza. Es un texto condensado que rescata la expresión cotidiana que forma la experiencia histórica común de los norteamericanos.

El libro está dirigido al público en general. Abarca del siglo XV hasta la sexta década del siglo XX y contiene ilustraciones e índice onomástico. Carece de aparáto crítico.

SNG

COLMEX 87. Sellers, Charles G. y Henry May, A synopsis of AmeriBerkeley Series in American History).

Con la idea de que la historia política es la mejor guía ordenadora de la vida económica y social, los autores intentan 
presentar una nueva síntesis dirigida a adultos neófitos en la materia. La obra está respaldada por el renombrado historiador Richard B. Morris. Escrita en estilo convencional, toma como punto de partida de su narración el año de 1607, concluyéndola bajo el signo de la "búsqueda de la nueva frontera" en el marco de la crisis permanente (19531963) de los años de Kennedy.

Al final de cada capítulo se incluye una breve cronología, así como algunas indicaciones bibliográficas.

GZP

COLMEX 88. Wright, Louis et al., Breve Historia de los Estados Uni973.004

B846

UNAM

E178.1

B73 dos de América, México, Limusa-Wiley, 1969, 606 p.

El libro, publicado en los Estados Unidos por primera vez en 1963, revisado y ampliado en 1968, cubre la historia norteamericana desde sus antecedentes en el sigloxvı hasta la década de 1960. El título original es The démocratic experience. A short American History.

UIA

E178

Sus editores, conscientes del problema que significaba la

W75 realización de una historia de los Estados Unidos que fuese a la vez breve y sucinta, pidiendo la colaboración de varios historiadores, cada uno de los cuales escribió acerça del periodo o tema que constituía su especialidad. Con todo, los participantes en la obra se hicieron el propósito de que las diversas secciones quedasen bien integradas. Sin embargo, debe señalarse que, aunque la Breve Historia de los Estados Unidos de América trata de reflejar un criterio común, no siempre lo logra. Cada una de sus partes muestra la personalidad intelectual y literaria de su autor y algunas son mejores que otras.

El texto pretende destacar los procesos por medio de los cuales "se perfeccionaron y se modificaron" (p. 6) las instituciones e ideas norteamericanas. Cada una de las ocho partes de que consta está organizada en tres capítulos. Los dos primeros de cada parte se refieren a la historia política y económica del periodo que estudian; el tercero se dedica a la historia intelectual y cultural.

La obra presenta, al terminar cada sección, una lista de referencias bibliográficas y, en sus últimas páginas, varios apéndices - listas de presidentes, vicepresidentes y miembros de los gabinetes, por ejemplo-, y un indice onomástico. Contiene ilustraciones y mapas.

ARSA

COLMEX 89. Degler, Carl N. et al., Historia de los Estados Unidos: 973 La experiencia democrática, México, Limusa, 1981,688 p.

H673

Este texto es la versión española de The democratic experience. A Short American History, en su cuarta edición inglesa, revisada, actualizada y publicada en los Estados Unidos en 1977. Como en la primera edición (1963), los autores son varios, ya que los editores solicitaron la colaboración de diez distinguidos historiadores, cada uno de los cuales escribió acerca de la época o aspecto que constituía su especialidad.

En relación a las versiones anteriores (véase núm. 88), la obra mantiene el concepto original, pero al mismo tiempo actualiza las referencias, las ilustraciones y el contenido - llega hasta el gobierno de 
Gerald Ford (1974-1976) - y considera con más detalle temas como el de las minorias y el de la cultura popular - revisa, por ejemplo, los intereses, diversiones y estilos de vida del norteamericano común-. Amplia las interpretaciones históricas de cada periodo a manera de mostrar cómo han sido percibidos por generaciones sucesivas de historiadores y de evaluar hasta qué punto se han cumplido los ideales de los padres fundadores.

El libro cuenta con referencias bibliográficas, mapas, ilustraciones y gráficas que facilitan la comprensión del proceso histórico. Al final tiene varios apéndices y un índice onomástico.

ARSA

COlMEX 90. Caughney, John Walton y Ernest R. May, $A$ History of 973 the United States, Chicago, Rand McNally, 1964, 813 p.

$\mathrm{C} 37 \mathrm{~h}$ Obra muy extensa de divulgación que carece de prólogo o introducción. Sus autores se dedican a describir un acontecimiènto histórico tras otro, esforzándose en realizar una narración amena, sustentada por varios anexos entre los cuales destacan dos: uno sobre población de origen extranjero (p. 738) y otro sobre estadísticas económicas (p. 739).

Lo voluminoso del texto, la ausencia de análisis y de una argumentación crítica, lo convierten en una historia carente de sentido cuya lectura resulta tediosa, ya que se limita a citar una secuencia de acontecimientos per se. Hace también éntasis en fechas, nombres y lugares.

Comprende del siglo $\mathrm{XV}$ hasta la sexta década del siglo $\mathrm{XX}$, además de contar con referencias bibliográficas por capitulo, mapas, cuadros estadísticos, ilustraciones y fotografías.

SNG

BNAL 91. Whitney, Frances, Síntesis de la historia de los Estados 973 Unidos, México, Libreros Mexicanos Unidos, 1964, 296 p. WHI.s Editado en el mismo año que en los Estados Unidos, se trata de un texto que intenta responder a la crisis de la hegemonia norteamericana planteada por la revolución cubana y cuya respuesta económica para América Latina fue el programa kennedyano de la Alianza para el Progreso. Así, la intención de la obra se concentra en no plantear duda alguna acerca de las verdades oficiales de la historia norteamericana, con un formato muy similar al de la Reseña (vease núm. 101) publicada por el Embajada Norteamericana en

1976. Contiene ocho capítulos, comenzando por la etapa colonial y cerrando con los Estados Unidos en la época contemporánea.

Una cita célebre de algunos de los presidentes abre cada uno de los apartados, que se extienden del primer asentamiento colonial (1607) a los inicios de la presidencia de John F. Kennedy (1961). Como apoyo bibliográfico, la obra, titulada en inglés An outline of American history, incluye 25 títulos cuyos autores en su gran mayoría son de corte conservador. 
COLMEX Traducción de The Americans. The national experience, 917.303 B724h publicada por primera vez en 1965.

V.2

Boorstin desarrolla en este volumen conceptos planteados en The Americans. The Colonial Experience (véase nota 73) donde niega la influencia de las ideas europeas en la vida colonial y sostiene que el carácter nacional fue moldeado en el periodo colonial por las situaciones y problemas concretos en las comunidades fronterizas. El sentido desarrollado en esta época da gran importancia a las soluciones prácticas y a las adaptaciones a las circunstancias concretas, lo que caracterizará al norteamericano de periodos posteriores. Así por ejemplo, los colonos se ven forzados a inventar su propia manera de hacer las cosas. Bajo esta perspectiva se enfocan temas como los inventos, la movilidad geográfica, la oŕganización de las comunidades, los empresarios, etc., en la etapa comprendida entre la revolución de independencia y la guerra civil. El libro no presenta bibliografía ni índice onomástico.

BBF

$\mathrm{S}$

973

MOR

\section{Morison, Samuel Eliot, Historia del pueblo americano,} Barcelona, LDE, Caralt, 1972, 2 vols.

Morison se propone recrear las formas de vida norteamericana en tiempos pasados. Sin olvidar la política, se apoya en el desarrollo social y económico. Se extiende desde el descubrimiento de América hasta la muerte de John F. Kennedy en 1963. El libro, publicado por primera vez en 1965 con el título The Oxford history of American people, da especial importancia a temas pocos tratados en otros textos, por ejemplo al poder marítimo, la población indígena, el - Caribe, Canadá, etcétera. Historiador del consenso, se muestra profundamente impresionado por la continuidad que, según él, ha caracterizado la historia de los Estados Unidos durante trescientos años.

Después de haber estudiado, enseñado y escrito sobre el pasado estadunidense durante casi medio siglo, el autor dirige este libro a sus compatriotas con la esperanza de que puedan leerlo y disfrutarlo. Por eso la obra carece de aparato crítico. Sin embargo, es interesante señalar que, al final de muchos de sus capítulos, se incorporan los trozos más representativos de la música popular de los Estados Unidos. Contiene también ilustraciones.

ARSA

COLMEX 94. Handlin, Oscar, The history of the United States, Nueva 973 H236h York, Rinehart and Winston, 1967, 2 vols.

Libro de texto dirigido a alumnos universitarios, a los que el autor caracteriza como parte de un mundo urbano e industrial. Handlin considera que las condiciones actuales requieren una nueva comprensión del mundo, pues, en la medida que los hombres marchan hacia el incierto futuro, miran para atrás con la esperanza de que si conocen el camino recorrido podrán apreciar mejor el que probablemente. recorrerán.

El método empleado por Handlin fue el siguiente: primero, evaluar cuidadosamente lo que un adulto estadunidense debe conocer de su pasado; luego, reunir los hechos y, finalmente, colocarlos den- 
tro de una estructura de ideas coherentes. No aceptó nada elaborado de antemano, ni datos, ni formas de organización o interpretación. Abandona el método convencional de tratar con las sucesivas administraciones presidenciales, por el de tratar los temas politicos familiares, además de los económicos, sociales y culturales. Prefiere estudiar tendencias a largo plazo aunque a veces hace narraciones individuales, incluso referencias biográficas de personas que de alguna forma dejaron su huella en la historia. Tiene estilo claro y directo.

La obra se extiende desde los antecedentes europeos del descubrimiento de América hasta los problemas externos e internos que los Estados Unidos enfrentan en la década de 1960. Consta de material biográfico y bibliográfico, mapas e ilustraciones.

ARSA

BBF

917.3

B724am

95. Boorstin, J. Daniel, The Americans; The Democratic Experience, 2a. ed., Nueva York, Vintage Books, 1974, 717 p. Publicada por primera vez en 1973, esta obra forma parte de una trilogía que comprende también The Americans: Colonial Experience y The Americans: The National Experience (véase núm. 73 y 93).

Este volumen gira en torno a la idea de que la centuria que siguió a la guerra civil (1865-1965) fue una "Epoca de Revolución": de incontables revoluciones silenciosas operadas en el seno de "el hogar y la granja, el taller y la escuela, los almacenes, el paisaje y la atmósfera" (p. IX). Las transformaciones profundas que trajeron consigo estas pequeñas revoluciones económicas, tecnológicas y sociales afectaron el medio físico norteamericano, su experiencia y sentido de comunidad, su significado de tiempo y espacio. La respuesta a estos cambios - plantea Boorstinse dio en términos del pragmatismo que caracteriza al norteamericano desde la Colonia, inventando una nueva comunidad democrática. Presenta al final una extensa bibliografía comentada e índice onomástico.

MTB

BBF

917.3

$\mathrm{COO}$

96. Cooke, Alistair, America, Nueva York, Knopf, 1973, 400 p.

Cooke, inglés de nacimiento pero naturalizado estadunidense, pretende en esta obra sintetizar la serie de programas televisivos dirigidos por él mismo acerca del acontecer histórico de los Estados Unidos.

Texto de divulgación, dirigido básicamente a la clase media estadunidense, la visión que da carece de crítica por estar imbuida del apasionado afecto del autor hacia su patria adoptiva, mismo que lo obliga a ignorar los conflictos y problemas que subyacen en el seno de su sociedad.

En el intento de describir en detalle cada acontecimiento del pasado y de exaltar a sus personajes, Cooke lleva a cabo un trabajo que podria calificarse de "reportaje histórico", o bien de "tour" a través del tiempo. El periodo que abarca la obra transcurre a partir de la aparición del hombre primitivo en el continente americano para concluir con el "American way of life" de los años setenta de nuestro siglo. Contiene abundantes fotografías - muchas de ellas tomadas por el propio Coo$\mathrm{ke}-$, ilustraciones, reproducciones pic̀tográficas e índice onomástico; se trata de una edición de lujo. Carece de aparato crítico. 
BBF 973 T

97. 200 Years. A bicentennial Illustrated History of the United States, Washington, U. S. News y World Report, 1973, 2 vols.

Dirigida a los lectores contemporáneos, la obra se extiende de 1763, término de la guerra de siete años, a 1972, año en el que se desarrolla la campaña electoral de Richard $M$. Nixon. Cuenta con dos secciones de lecturas - formadas con cartas, documentos, diarios y canciones- y varias de ilustraciones, en las que trata someramente los temas sociales y económicos de la historia norteamericana. Al comenzar cada capítulo presenta breves cronologías y al final de cada volumen presenta una "galería presidencial" con biografías de cada presidente de los Estados Unidos y un indice onomástico. Carece de aparato crítico.

Los diversos autores del texto llevan a cabo una historia política tradicional. Piensan que la "experiencia" estadunidense es "la mejor esperanza mundial" y que "nadie puede revisar la historia de la nación desde 1776 sin orgullo por sus enormes realizaciones" (vol. 1, p. 8). Aceptan que los norteamericanos, que viven en un ambiente de cambios perturbadores, de conflictos, de rivalidades y ansiedades, son ya conscientes de sus limitaciones. Mas cuentan con abundantes valores para enfrentar su momento. Así, por ejemplo, el sistema de gobierno, con una supervivencia de 200 años.

Se concluye con una cita de Walt Whitman, que en alguna medida caracteriza el espíritu de la obra: "Cuento con... absoluta certeza en el gran futuro de los Estados Unidos" (vol. 2, p. 288).

ARSA

FLUNAM 98. Boorstin, Daniel J. et. al., Estados Unidos, una civilizaE 169 1 B64 ción, Barcelona, Labor, 1975. 350 p.

Traducción de American Civilization, editada por primera vez en 1975, esta obra, dirigida por Boorstin, se compone de los trabajos de trece especialistas sobre temas "notables, interesantes o característicos" de la civlización norteamericana, desde el descubrimiento de América hasta la guerra de Vietnam, con un marco histórico de fondo. El libro no es propiamente una historia de los Estados Unidos, sino una descripción de los resultados de esta historia en sus instituciones, sistemas de producción, en la ciudad, el campo, y en el arte del presente siglo.

Los autores parten de la idea de que la civilización de los Estados Unidos es única y que en Norteamérica las instituciones, organizaciones e ideologías europeas adquieren un carácter distinto. Pretenden destacar la continuidad, unidad y homogeneidad de la sociedad norteamericana y negar la existencia de contradicciones entre las clases sociales. Consta de ilustraciones y mapas.

MTB

BBF 99. Jacobs, David, Disney's America on parade. A history of 973 the U.S.A. in a dazzling, fun-filled pageant, Nueva York, J Harry N. Abrahams, 1975, 144 p.

Para conmemorar el bicentenario de la independencia estadunidense, deseosa de celebrar adecuadamente lo que llamó la "fiesta de cumpleaños de la nación", la organización Walt Disney lleva a cabo, entre 1975 y 1976, más de doce 
mil desfiles en sus centros de diversión en California y Florida. Se trata de exhibiciones basadas en la historia social de los Estados Unidos, mismas que son contempladas por unos 25 millones de personas. Con el mismo afán, el sistema Disney produce programas de televisión, libros y discos. Dirigida a un amplio público, esta obra trata de mostrar, con ilustraciones y fotografias apropiadas, el espíritu de esa celebración. Su texto, escrito por David Jacobs, abarca de los antecedentes europeos del descubrimiento de América a la década iniciada en 1970. Carece de aparato crítico.

Con ánimo consensual, el autor habla de las realizaciones del pueblo de los Estados Unidos, de su crecimiento demográfico y estilo de vida. Exalta los grandes momentos de su historia - por supuesto, no incluye temas como la guerra en Vietnam - . Describe a sus habitantes como poseedores de las mismas aspiraciones: "vivir en libertad, con un grado razonable de comodidades materiales, ... ir tan lejos como su ambición, talento y diligencia se lo permitan" (p. 129). Acepta la diversidad característica del país, la existencia de pobres y ricos, negros y blancos, conservadores y liberales. Pero considera que ésta no sólo es una gran realización sino la mejor rạzón para celebrar su "cumpleaños" y que, al fin y al cabo, los norteamericanos están atados por un mismo lazo: "La convicción de que deben preservar su herencia democrática" (p. 138).

ARSA

UIA

E178

R48

\section{Reseña de la historia norteamericana, s.p.i., 194 p.}

Todavía en la época de la política de distensión y como parte de los esfuerzos por lavar la herida causada por la derrota en Vietnam (una "paz con honor" según la versión oficial), el gobierno norteamericano puso especial interés en la conmemoración del bicentenario de la independencia del país (1776). Con ocasión de esta celebración el Servicio de Información de los Estados Unidos, dependencia de su Embajada en México, publicó este texto, del cual, obviamente, hay que esperar una versión típica del "consenso", afín a la ideologia conservadora, en la que confluyen autores demócratas, como Link y Sorensen, y republicanos, como Degler, Handlin, Nevins, entre otros.

A pesar de que es una visión bastante esquemática de la historia norteamericana, por su modo hábil de argumentar cumple de lleno con su propósito divulgador, por no decir propagandístico. Se compone de ocho capítulos, abriendo con el periodo colonial y cerrando con el título neutro de "los Estados Unidos en el mundo moderno". Conquistada la independencia, formado el gobierno nacional, la violencia que conlleva la expansión hacia el oeste, la guerra civil y las guerras imperiales serán entendidas bajo el rubro de "conflictos" inevitables, finalmente, en la lógica del "Destino Manifiesto". Carece de aparato crítico.

GZP

COLMEX 101. Morison, Samuel Eliot et. al., Breve historia de los Esta973

M861 B dos Unidos, México, FCE, 1980, 968 p.

El texto de esta obra, publicada en inglés en 1977 con el ponde a W. E. Leuchtenburg, quien, para su elaboración, 
973

MOR

BIM

973

MOR.b

tomó abudante material de la Historia de los Estados Unidos de Norteamérica, redactada por Samuel E. Morison y Henry S. Commager y editada en varias ocasiones entre 1930 y 1969. Leuchtenburg siguió también las numerosas recomendaciones que en las diversas fases de su trabajo le hicieron los propios Morison y Commager.

Con el enfoque del consenso, los tres historiadores coinciden en que la historia comprende todas las actividades de un pueblo, tanto las económicas y sociales, como las políticas y militares. Por lo tanto, en la Breve historia de los Estados Unidos se han esforzado por subrayar esos diferentes aspectos, para mostrar así una civilización en constante cambio y desarrollo y un pais en continuo crecimiento.

El libro, dirigido al público en general, tiene una narración agradable y concisa, de manera que permite un primer contacto con la historia norteamericana. Abarca desde el descubrimiento de América hasta 1976, año en que los Estados Unidos celebraron el bicentenario de su independencia. Carece de aparato crítico, pero cuenta con un buen indice onomástico y mapas.

ARSA

BBF

973

$\mathrm{BOO}$

102. Boorstin, J. Daniel et al., $A$ history of the United States, Lexington, Mass., Ginn, 1981, 828 p.

Una obra más de la abudante producción del influyente autor estadunidense. En ella Boorstin parte de la idea de que: "La historia americana es la historia de una transformación mágica" (del prólogo). Transformación que lleva a hombres y mujeres, venidos de un viejo y cansado continente, a explorar un mundo nuevo en búsqueda de lo que significa ser estadunidense. La débil y pequeña confederación que firma la independencia en 1776 se convierte, después de 200 años, en "la democracia más grandiosa del orbe, refugio del mundo; en la nación más fuerte de la tierra" (del epílogo).

Dirigido a estudiantes de high-school, el texto abarca desde el descubrimiento de América hasta la presidencia de James Carter. Contiene magníficas ilustraciones, fotografías, mapas y elementos didácticos tales como cuestionarios y ejercicios. Incluye índice onomástico.

MTB

\section{Corriente revisionista o de la "multihistoria"}

COLMeX 103: Current, Richard Nelson et al., American History: $A$

973

C976a

BBF

973

CUR
Survey, 4a. ed., Nueva York, A. Knopf, 1975, 911 p.

La obra pretende servir de guía aclaratoria del proceso histórico norteamericano. Apareció originalmente en 1959. El prefacio de esta edición advierte que el texto ha sido revisado y actualizado con el propósito de dar a los estudiantes de educación media una visión más completa de la sociedad de los Estados Unidos.

El libro incorpora debates historiográficos revisionistas que presentan interpretaciones de conflicto en torno a cuestiones tales como el papel de las minorías o el de la mujer, recalcando que éstas son parte integral de la complejidad histórica estadunidense.

Incluye temas económicos, políticos, sociales y culturales"del perio- 
do histórico que va del siglo XV hasta la séptima década del siglo XX. Contiene ilustraciones, fotografías, mapas, gráficas, cuadros, bibliografías por capitulo, apéndice documental e indice onomástico.

SNG

colmex 104. Baldwin, Leland D. y Robert Kelley, The Stream of 973 American History, Third Edition, Nueva York, American B17xe Book, 1965, 832 p.

UNAM Leland D. Baldwin, autor de The Stream of American E178 History, publicada por primera vez en 1952, reorganizó y Bis escribió de nuevo la obra para esta tercera edición, con la colaboración, en cuanto a los detalles y la interpretación, de Robert Kelley. Este último se hizo responsable de las ilustraciones, la bibliografía, el indice onomástico y el ensayo preliminar titulado "La profesión del historiador".

Los dos autores tratan de que su historia sea algo más que una mera crónica de acontecimientos que, al fin y al cabo, pueden ser seleccionados y ordenados de tal manera que puedan probar cualquier punto de vista. $Y$, aunque saben que pretenden algo imposible y aun indeseable, se esfuerzan por ser objetivos. Por ello, consideran también las opciones, las contradicciones y los conflictos presentes en el proceso histórico de los Estados Unidos. Comienzan su escrito con los antecedentes europeos del descubrimiento de América y lo terminan en los primeros años de la década de 1960. Pretenden que el tema central sea el intento estadunidense de conjugar sus ideas de dignidad y libertad humanas con la demanda de que los recursos materiales y culturales no pertenezcan a una minoría privilegiada, sino que sirvan a todos.

El libro incluye, al término de cada capítulo, una recomendación de lecturas para ampliar el conocimiento de los distintos temas. Al final proporciona una bibliografía general, una serie de documentos, listas de presidentes, vicepresidentes y miembros de los gabinetes presidenciales, cuadros estadísticos e índice onomástico. Contiene mapas.

ARSA

COLMEX 105. Fohlen, Claude, La América anglosajona de 1815 a 973 nuestros días, Barcelona, Labor, 1967, 314 p. (Nueva Clio: F657s La Historia y sus problemas).

BNAL Publicada por primera vez en París en 1965 como L'Amé970.05 rique anglo-saxonne de 1815 à nos jours, la obra pretende es$\mathrm{FOH}$.a. bozar la problemática histórica de ka "América anglosajoUNAM na", término con el cual se designa a los Estados Unidos y E175 Canadá. El autor, profesor universitario en Francia, consiF6 dera que los dos países tienen mucho en común, tanto por el idioma inglés y el tipo de vida como por su condición de antiguas colonias británicas.

El libro se divide en tres partes. En la primera se tratan las historias estadunidense y canadiense a partir de 1815, año en que, después de la guerra con Gran Bretaña, los Estados Unidos logran su verdadera independencia frente a Europa y en que Canadá consigue cierta participación política de la oposición en el gobierno local. Se termina en la década de 1960, cuando el partido demócrata norteamericano triunfa sobre el republicano y cuando los conservadores canadienses son derrotados.

En la segunda parte, Fohlen revisa los desarrollos y debates historio- 
gráficos más importantes en la América anglosajona. Subraya los rasgos comunes y las diferencias en la historia de los paises que la forman. Respecto a la historia de los Estados Unidos, reconoce sus éxitos: el triunfo de la democracia política y el asombroso desarrollo material. Pero indica que su continuidad es aparente, que no ha carecido de rupturas y que el futuro vislumbrado incluye graves conflictos - tensiones raciales, por ejemplo-. El autor dedica el último apartado a la considerable documentación existente sobre los temas que trata: documentos impresos y de archivo, fuentes bibliográficas y estadísticas. Incluye mapas y un indice onomástico.

ARSA

BBF 106. Garraty, John A., The American nation, a history of the

RC United States, 4a. ed., Nueva York, Harper \& Row, 1979, $973 \quad 864$ p.

GAR El autor, profesor de la Universidad de Columbia, publicó esta obra por primera vez en 1966. En esta nueva edición se pone al dia la interpretación de la historia norteamericana, actualizando la bibliografía consultada y acentuando aspectos de la historia social relacionados con las mujeres, los negros y "otras minorías". Considera Garraty que esta historia constituye la epopeya de una experiencia única de la humanidad, desarrollada en un territorio vasto, al principio casi deshabitado y ahora poblado por más de 200 millones de gentes. Como historiador no intenta predecir, sólo situar al lector en su momento histórico. No oculta la idea de que la historia es obra de las grandes personalidades, aunque influidas por los acontecimientos.

Dirigido a un amplio público, el texto está presentado con bastantes recursos didácticos: mapas, ilustraciones, índices, montos de la población entre 1790 y 1970, apéndices y bibliografías complementarias para cada capítulo. Dividido en 31 capítulos, el relato transcurre desde el descubrimiento de América hasta la guerra de Vietnam y la administración Carter. Intercala seis ensayos muy bien ilustrados sobre la herencia dejada por los pueblos africanos, Benjamín Franklin y su época, la Norteamérica vista por Tocqueville, los indios de las grandes llanuras, la situación de la mujer en la sociedad de finales del siglo XIX y el desarrollo de la pintura en el siglo $\mathrm{XX} .^{40}$

COLMEX 107. Schoell, Franck, Historia de los Estados Unidos, Bil973 bao, Moretón, 1968, 380 p. (Biblioteca de divulgación culS364h tural. Panorama de la Historia Universal, 3).

Siendo la edición original francesa, el autor no sale de su asombro de cómo un europeo se transformó en "americano" Locke en Carnegie y Ford. El nacimiento de la democracia norteamericana coincide con la aparición de la máquina de vapor y La riqueza de las naciones de Adam Smith. Defensor Schoell de la tesis del "excepcionalismo" norteamericano, no oculta, sin embargo, su preocupación por los

40 En la biblioteca Benjamín, Franklin se encuentra una versión sintetizada de esta obra, en la que el autor respeta casi integramente el texto original. Sólo el capitulo referjdo a la guerra de Vietnam forma parte del capitulo 30 . Su referencia bibliográfica es $A$ Short History of the American nation, Nueva York, Harper \& Row, 1974, 532 p. Su clasificación bibliotecaria es 973/GAR. 
problemas raciales, e incluye referencias explícitas al de los indios.

El manual está dividido en tres grandes apartados: el periodo colonial, el de la expansión continental (1783-1898) y el de la conversión de los Estados Unidos en potencia mundial (1898-1965). De alguna manera concluye lo evidente: el "American way of life" se ha impuesto en el mundo después de la segunda guerra mundial -mediante el plan Marshall - la sobreproducción norteamericana encontró tierras fërtiles en la Europa devastada. Asimismo, observa el cambio del balance de poder industrial, financiero y demográlico de la cuenca del A tlántico a la costa del Pacilico.

Contituye una sintesis aceptable de la historia norteamericana con un estilo fácil de seguir. Al final se incluyen algunos breves apéndices sobre bibliografía, cronología, etc. El original francés se tituló Histoire des Etats-Unis. La versión espanola no señala la fecha de la primera edición.

GZP

Colmtx 108. Woodward, Vann C. (comp), Historia comparada de 973 Los Estados Unidos, México, Letras, 1971, 368 p.

W912n Woodward, profesor de la Universidad de Yale, reúne en BBt este libro diferentes ensayos de reconocidos historiadores $S$ sobre algunos de los temas clásicos de la historia estaduni973 dense como colonia, revolución, frontera, inmigración, esHIS clavitud, guerra civil, industrialización, grandes corporaUIA ciones, urbanización, socialismo y trabajo, partidos políti178.6 cos, socialdemocracia, guerras mundiales, crisis económiW66 cas, etcétera.

Originalmente publicada en inglés como $A$ comparative Approach to American History, 1968, intenta, a la manera de la estación radiodifusora La Voz de las Américas, misma que es la editora, familiarizar a un público extranjero, intelectual y profesional, con los grandes temas históricos estadunidenses en términos comparativos. En la mente del compilador está el llenar un campo descuidado por los historiadores, no tanto por los cientificos sociales: el de la historia comparada. El estilo en general es sencillo e ilustrativo, útil para profundizar ulteriormente los tópicos particulares de la historia de los Estados Unidos.

Cada capitulo -24 en total- incluye al linal una breve bibliografía comentada.

GZP-MEL

COLMEX 109. Border, Morton, The American Profile, Lexington, 973 B728:a

Mass., D. C., Heath, 1970, 372 p.

La obra es altamente selectiva, por lo que su autor menciona la posibilidad de haber incurrido en la subjetividad, misma que haría quesu interpretación histórica fuese motivo de gran controversia.

Su objetivo principal es servir de introducción y guía a los estudiantes universitarios interesados en la investigación histórica, con el afán de despertar en ellos la motivación y el cuestionamiento sobre ciertos tópicos clave de la historia norteamericana de manera que los lleven a anondar en su estudio.

Texto muy conciso que expone una sólida visión general de la historia de los Estados Unidos desde 1700 hasta la séptima década del siglo $\mathrm{XX}$, partiendo de una postura intelectual. 
Contiene interesantes ilustraciones y mapas, además de una lista de sugerencias bibliográficas por capítulo.

$\mathrm{BBF}$

S973

110. Cárdenas Nannetti, Jorge, Nuevahistoria de los Estados

CAR

Unidos, Nueva York, Editorial Moderna, 1970, 466. p.

Desde una perspectiva latinoamericana, el autor, de origen colombiano y exdirector de la revista "Selecciones del Reader's Digest", intenta con este libro reformular la historia de los Estados Unidos para conocer la verdad sobre "la segunda conquista de Méjico", el "drama y escándalo de Panamá", el "imperialismo yanqui", etcétera.

Creyente de los valores de la democracia estadunidense, el escritor pretende informar de manera "rápida y concisa" a un público latinoamericano acerca "del fenómeno más asombroso y más importante de nuestro tiempo", sin ocultar tampoco aspectos controvertidos, sólo presentes en las historias académicas, mas no en las de divulgación de los Estados Unidos. Sin duda, el libro de Cárdenas tiene una presentación inteligente de la historia estadunidense y expresa una conciencia clara de la necesidad de comprenderla desde nuestra perspectiva, dada su vecindad y el impacto que ha tenido y tiene en los Estados latinoamericanos, e incluso a nivel mundial.

Aunque editado en Nueva York, el libro está impreso en Bogotá y el prólogo del autor remite al año de 1965 . Está dividido en 30 capítulos desde el descubrimiento de América hasta la presidencia de Lyndon B. Johnson. Contiene mapas y un indice al final, y respecto a la bibliografia consultada, aparece de vez en cuando a pie de página. Utiliza "textos de la localidad" cuando México, Cuba o Colombia han sido implicados en la urdimbre histórica estadunidense.

GZP

BBF

973

LIN
111. Link, Arthur S. y Stanley Coben, The Democratic Heritage: A History of the United States, Waltham, Mass., Ginn, 1971, 674 p.

Ambos autores dirigen expresamente su obra a estudiantes norteamericanos universitarios con el propósito de darles a conocer su pasado y ayudarles a "entender" el porqué del presente. La historia aparece como un continuo proceso de cambio que parte del desarrollo de las instituciones políticas. Además, trata tópicos como el del crecimiento urbano y las diferencias entre ricos y pobres.

El texto gira en torno al concepto de "democracia" y la manera en que dicho ideal ha ido confrontándose con la realidad. La heterogeneidad y pluralidad social de los Estados Unidos aparece "unida" por el idealismo democrático. Partiendo de una posición institucional, Link y Coben no sólo describen sino que analizan el significado que las fuerzas económicas, sociales e intelectuales han tenido en la conformación actual de Norteamérica, a través de esquemas metodológicos novedosos (por ejemplo la "nueva historia política").

La obra comienza con la expansión europea en tierras americanas, durante el siglo $X V$, y cierra con la presidencia de Nixon, a fines de los años sesenta de nuestro siglo.

Contiene sugerencias bibliográficas por capítulo, mapas, ilustracio- 
nes, fotografías, apéndice documental con cuadros de información política e índice onomástico.

BBF

873

GRU

112. Gruver, Rebecca Brooks, An American History, 2a. ed., Reading, Mass., Addison-Wesley, 1976, 1022 p.

La obra es la versión modificada y restructurada sustancialmente de la primera edición del mismo título, publicada en 1972. A través de un lenguaje claro y sencillo, se hace una presentación coherente del devenir histórico de los Estados Unidos desde el encuentro entre europeos y americanos en el siglo XV, hasta la presidencia de Ford en la séptima década del presente siglo.

Con la intención de hacer comprensible las fuerzas económicas, políticas, sociales y culturales que han intervenido en la conformación del pasado estadunidense, el libro menciona los conflictos y diferencias surgidos entre ellas, para concluir que su conocimiento no puede darse en términos de uniformidad y armonía. Sin embargo, no desconoce la importancia del idealismo del pueblo estadunidense y afirma que el dilema central de la historia norteamericana ha sido el llevar a la praxis los ideales de libertad y democracia.

El libro trata temas como el problema obrero, la lucha de las mujeres y de las minorias étnicas, la transición del modelo económico agrícola al industrial y la importancia básica del sector empresarial en la creación del sistema capitalista.

Contiene bibliografía por capítulo, apéndice documental, cuadros estadísticos, indice onomástico, mapas, ilustraciones y fotografías.

SNG

BIM

973.8

113. Wasserman, Harvey, Harvey Wasserman's history of

WAS.h

the United States, introducción de Howard Zinn, Nueva York, Harper \& Row, 1972, 262 p.

Obra realizada en todos sus detalles (desde el papel que es reciclado) con el espíritu más heterodoxo. Dirigida a un amplio público, está escrita en un lenguaje sencillo, directo, a la vez cargado de ironía. Su estilo narrativo, siempre fluido, rompe con todos los esquemas de las historias académicas, de corte formalista, en apariencia objetiva.

El relato se centra en la etapa que se inicia con el término de la guerra civil y se cierra con las grandes luchas socialistas de la segunda década de este siglo. Por sus páginas se ven desfilar a los magnates de las grandes corporaciones ("robber barons") y las luchas que contra éstos emprenden los grupos agrarios del movimiento populista y los miembros del movimiento obrero con sus exploraciones de Haymarket, Chicago... sin descuidar el papel de los Caballeros del Trabajo, de la American Federation of Labor (AFL) y de los "wobblies", la gran huelga de Lawrence y la masacre minera de Ludlow. El autor titula al último capítulo -escenario de las luchas feministas, de los negros... de la generación primera de la revolución industrial capitalista del último cuarto de siglo - "the days for magic".

La misma presentación de las notas intenta no romper el tono crítico narrativo que permea toda la obra. No hay apartados rígidos, tan sólo puntos suspensivos que se dan pie unos a otros. El texto es una secuencia ininterrumpida, sin límites. Por lo demás, únicamente la notas ha- 
cen referencia a la bibliografía consultada, correspondiente a cada uno de los capítulos.

BNAL 114. Hoogenboom, Ari y Olive Hoogenboom, An Interdis973 HOO.i ciplinary Approach to American History, Englewood Cliffs, N. J., Prentice Hall, 1973, 2 vols.

Bajo el influjo de ideas y métodos de las ciencias sociales en la escritura de la historia norteamericana, los compiladores intentan en estos volúmenes reunir trabajos previamente publicados por especialistas sobre tópicos que van desde los análisis antropológicos, sociológicos, económicos, psicológicos, etc., hasta los estudios de medicina, folclore y música.

La temática cubre aspectos relacionados con los indios, la familia, la agricultura, la religión, la economía y la politica, la estructura y movilidad social, la mujer, la esclavitud y los negros, la guerra civil, la inmigración, el imperialismo, corrientes politicas reformistas, etcétera.

Dado que la selección está dirigida a estudiantes preuniversitarios (college) los realizadores de esta antología han eliminado todo aparato crítico, señalando sólo la fuente original del texto y un breve prólogo introductorio sobre los autores y el contenido del ensayo. Si se pudiera señalar una periodización, los artículos -49 en total-cubren temas clásicos, relevantes o novedosos, que van del siglo XVIi al XX.

BNAL 973

BOL.h

BIM

973

BOL.h

115. Bolt, Christine, A History of the U.S.A., Londres, MacMillan, 1974, 730 p.

El libro traza el devenir histórico de los Estados Unidos desde su independencia hasta la séptima década de la presente centuria; incluye un capítulo de introducción que trata el legado colonial con el objeto de explicar el origen del carácter norteamericano.

La intención de su autora es hacer una interpretación de los momentos clave y las paradojas de la historia de los Estados Unidos, además de introducir al lector en importantes debates historiográficos.

Como resultado del tratamiento temático del libro, se da menos importancia a la historia politica convencional, ampliamente considerada por los libros de texto en general. Centrando su atención en lo económico, Bolt realiza un trabajo sintético que parte del supuesto de que el crecimiento de la democracia estadunidense ha sido firme, pudiendo salvar los obstáculos que se le presentan y asimilando una serie de reformas con el propósito de adaptar a nuevas condiciones a la sociedad estadunidense.

Contiene una cronología analítica por capítulos, un esquema del sistema de gobierno, mapas, fotografías, apéndice y una bibliografía general.

SNG 
que por su estilo narrativo pretende mantener el interés de una generación de estudiantes escépticos e inquisitivos. Profundiza algunos temas conflictivos como las relaciones raciales y étnicas referidas especialmente a los negros, indios, inmigrantes y otras minorias oprimidas. También se consideran la lucha por las libertades politicas y el mejoramiento económico, los conflictos de clase, la expansión territorial, las transformaciones tecnológicas. Los autores, para lograr su cometido, combinan en el relato el dramatismo de los hechos y la interpretación conceptual, rescatando la "experiencia" norteamericana a lin de que el lector haga también su propia historia.

El texto se abre con cuatro episodios referidos al descubrimiento de América y lo cierran otros cuatro sobre la crisis de los misiles en Cuba, la batalla de Chicago en 1968, la llegada a la Luna y el episodio de Martin Luther King. Dividido en 38 capítulos ordenados en siete unidades - colonia, revolución, federalismo, secesión, industrialización y modernidad, hasta Eisenhower y la época reciente - que dan principio con un ensayo pictórico y se terminan con una bibliografía historiográfica y literaria. Incluye abundantes fotografías e ilustraciones, asi como cuestionarios con fines didácticos.

MTB

$\mathrm{BBF}$

973

KEL
117. Kelley, Robert Lloyd, The shaping of the American past, Englewood Cliffs, N. J., Prentice-Hall, 1975, 1002 p.

De los antecedentes ingleses de la colonización de América del Norte a la crisis de Watergate (1973-1974), la obra describe las grandes luchas políticas, que han dado a los Estados Unidos - según el autor - los medios para hacerse a sí mismos conscientemente.

No lo hace a la manera tradicional, sino desde el marco de la "nueva historia política", con un enfoque cultural. Trata de lograr que la narración sea como "la vida misma": plural, multifacética, mezcla de emociones, imágenes, motivos económicos. No olvida entrelazarla con la historia de los oprimidos y los desposeídos: negros, mujeres, indios, inmigrantes, obreros y campesinos.

Considera Kelley que los estadunidenses han realizado, a través de su historia, muchos de sus sueños. Pero que luchan aún con gigantescos males que, en cierta forma, son peores que en el pasado. Su sociedad, ahogada por los desperdicios de la opulencia, aterrorizada por las armas nucleares, por el crimen, por la drogadicción, por el poder excesivo de los funcionarios... amargada por la pobreza degradante y lastimosa de muchos de los que la integran, viciada por los prejuicios y la desigualdad, no tiene ya fe en su dorado futuro, no cree que los Estados Unidos sean ni un ejemplo para el mundo, ni la sede de la igualdad y la democracia.

Ahora bien, aunque el autor es capaz de reconocer los males del sistema en que vive, no lo cuestiona de raiz. Concluye que para realizarse, un estadunidense debe regresar a los ideales de la Declaración de Independencia y a la cautela de la Constitución. Tal vez esto es lo más que se puede hacer. Su país, ya no tan joven, sabe que la felicidad es difícil de alcanzar y que a lo más a que puede aspirar es a "dejar su huella y hacer al mundo mejor de lo que ha sido" (p. 1002).

Dirigido a estudiantes universitarios, el libro se inicia con un breve ensayo en el que se analiza la labor del historiador y concluye con otro 
retrospectivo, que pretende hacer reflexionar a los alumnos sobre lo que han leido. Propone lecturas complementarias - documentos y textos historiográficos relevantes-. Presenta, al final de cada capitulo, un comentario y sugerencias de lecturas. Contiene cronologias, cuadros, un apéndice documental, una bibliografia general, un indice onomástico, ilustraciones y mapas.

ARSA

BBF 118. Jones, Peter d'A. The U.S.A. A history of its people and society, Homewood, III., Dorsey Press, 1976, 2 vols. (The Dorsey Series in American history).

Esta obra está redactada en dos volúmenes, uno que va desde 1492 hasta 1877 y otro que retoma desde 1865 hasta la elección de 1972. Es un libro de texto para estudiantes universitarios que, por supuesto, ya han estudiado la historia de su pais en la escuela primaria y secundaria. Cada capítulo termina con una pequeña pero selecta bibliografía. Contiene mapas y un apéndice con documentos y gráficas.

El autor explica en el preámbulo que su obra pertenece a la corriente revisionista puesto que da más importancia a la historia social, étnica y económica, que a la política y militar. Afirma que su libro es un "texto con opiniones", ya que en cada periodo trata de proporcionar tantos argumentos como el espacio lo permite. En cuanto al tratamiento de temas fundamentales, tales como la revolución de independencia, la industrialización, etc., adopta una postura comparativa respecto a los movimientos parecidos de diferentes épocas, los cuales dan una nueva perspectiva a los acontecimientos estudunidenses.

AMP

BBF

973.9

$\mathrm{KOL}$
119. Kolko, Gabriel, Main currents in modern American history, Nueva York, Harper \& Row, 1976, 433 p.

Desde una perspectiva histórica, el autor reconsidera la interacción entre economía política y política exterior. La obra constituye el trabajo más importante de Kolko pues realiza una nueva sintesis de sus trabajos anteriores, siempre controvertidos. Inmanente al análisis va la crítica a la carencia de autocritica (chovinismo) que ha marcado a la historiografía norteamericana desde las últimas décadas del siglo XIX hasta la derrota en Vietnam, a cuya revolución triunfante está dedicado el libro. Profesor de la Universidad de York en Toronto, Kolko es uno de los representantes más conocidos de la "nueva izquierda".

El texto se divide en 10 capítulos que cubren de 1870 a 1976, en los que se tocan temas relativos a la época de la reconstrucción, al papel de la clase obrera norteamericana, las crisis del capitalismo y la permanencia de la política exterior de 1946 a 1975. El autor denomina a este periodo como "la estructura del capitalismo político". Incluye referencias bibliográficas en cada uno de los capítulos y un indice temáticoonomástico al final.

GZP 2 vols. 
Es una introducción a la historia norteamericana dirigida no a profesionales de la historia, sino al ciudadano común. Encuadrada en la corriente revisionista de la "nueva historia social" y como parte de la tradición iniciada por F. J. Turner, D. Boorstin y R. Billington, el autor pretende examinar de cerca aquellas experiencias e instituciones que se podrian definir como "tipicas norteamericanas". Su interés central está en destacar las èxperiencias de seres humanos que sufren, se apasionan, aman y se equivocan, viven y mueren. Experiencias existenciales que se reflejan en la democracia, la frontera, las guerras y las ciudades; o en la ciencia, tecnologia e industria, a modo de luerzas transformadoras; o en instituciones como la familia y la Iglesia; o en las artes y modos de divertirse y descansar; o en forma de destino en el caso de los inmigrantes, negros e indios.

La obra está organizada en 4 grandes apartados: el primero transcurre de 1492 a 1787 , referido a los fundamentos de la "civilización norteamericana”, el segundo se extiende de 1787 a 1877 , época de la formación de la nación, expansión territorial y guerra civil; el tercero, que se refiere a la entrada de la nación a la época moderna, 1865-1918; y el cuarto que va de 1919 a 1975 . Cada capitulo está precedido por "el espiritu de la época" o nota dominante del periodo tratado, y cierra con el perfil biográfico de una personalidad conocida, o, en muchos casos, desconocida. Con ello el autor recuerda al lector que la historia norteamericana es la historia de seres humanos vivos, en quienes pone su esperanza por una Norteamérica cada vez mejor.

El texto está escrito en un lenguaje demasiado estilizado, lo que hace su lectura de difícil comprensión. Contiene mapas y fotografias e incluye al final una bibliografía comentada, apéndices y un índice temáticoonomástico.

GZP

Colmex 121. Adams, Willi Paul et al., Los Estados Unidos de Améri$908 \quad c a, 4$ a. ed., México, Siglo XXI, 1980,494 p. (Historia Univer-

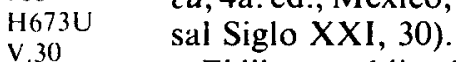

V.30 El libro, publicado por primera vez en Alemania en 1977 ,

BNAL presenta la historia de los Estados Unidos desde 1763, año

ADAM.e en que termina la guerra de siete años, hasta 1976. La estu-

1979 dia a través de procesos clave como los de la revolución industrial, el imperialismo, la emigración en los siglos XIX y

UIA XX, etc. Debido a las limitaciones de espacio, relega la histoV 478 ria diplomática y militar en favor de una historia social y económica.

Dirigida a lectores europeos sin conocimiento previo de la historia norteamericana, la obra fue escrita por varios autores ingleses. La compilación y parte de la redacción estuvieron a cargo de un alemán, Adams. Los autores pretenden superar el eurocentrismo tradicional de la historia universal, sin caer tampoco en un "americentrismo".

El texto contiene un aparato crítico y un anexo útil. Utiliza una bibliografía completa, en la que se incluyen las aportaciones más recientes de la historiografia de los Estados Unidos. Su título original en alemán es Die vereinigten Staaten von Amerika.

ARSA

COLMEX 122. Bailyn, Bernard et al., The great republic, a history of 973 the American people, Lexington, Mass., Heath \& Co., 1977, O786 1267 p. 
$\mathrm{BBF}$

973

GRE

Inspirado el título en la frase acuñada por Winston Churchill, los seis autores, historiadores de las universidades de Harvard, Brown, Northwestern y Yale, se proponen en esta obra mostrar la "grandeza" de Norteamérica, pero sin ocultar tampoco que la distribución de la riqueza económica, política y cultural está todavía lejos de alcanzar los ideales de justicia social.

La narración explicativa transcurre desde los primeros asentamientos europeos en América hasta 1976, año de la conmemoración del bicentenario de independencia. Cada una de las seis secciones en que se divide, contiene un tema particular expresado en breve introducción. Así, en torno a dos temas centrales: a) desarrollo de las instituciones políticas y b) la tensión permanente entre el gobierno de las mayorías y las minorias, entre las "sociedades fragmentos" originales (Louis Hartz), etc., se escribe sobre formación, fundamentos, expansión, unificación, nacionalización, y modernización de la República. Será, pues, el "republicanismo", el que proporcionará las instituciones idóneas para mediar en los conflictos culturales, raciales, étnicos, sociales, etcétera.

El texto, dirigido a un amplio público, es sin embargo, de corte académico. Cada capítulo - 35 en total - incluye al final una breve bibliografía comentada. Los seis apartados tienen además de la introducción inicial, un breve ensayo sobre arte y pintura y una breve cronología. Está ilustrado con mapas, fotografías, caricaturas, etc. Al final se incluye un apéndice con documentos básicos y algunos registros sobre población y elecciones presidenciales. No falta el índice temático-onomástico.

GZP

$\mathrm{BBF}$

$\mathrm{S}$

973

DOL
123. Dollar, Charles M., ed., America changing times, 2a. ed., Nueva York, John Wiley \& Sons, 1982, 2 vols.

Los autores, especialistas coordinados por el historiador y escritor John Hammond Moore, entregan un libro que pretende ser una historia política y económica de los asuntos domésticos e internacionales. Se concentra en la descripción y explicación de instituciones tales como la familia, la empresa, etc., y de procesos como el tecnológico y el de la urbanización. Intentan exponer los cambios habidos en la continuidad de la historia norteamericana sobre la base de que ésta ha sido obra de toda clase de gente "de los grandes y pequeños héroes y villanos".

Texto perteneciente a la corriente revisionista metodológica que trata de rescatar los valores de "la gente" estadunidense (no necesariamente del pueblo), con su pluralidad étnica, su individualismo creador, en igualdad de oportunidades, que ha inventado una "civilización vibrante que gran parte del mundo quiere emular".

El primer volumen se inicia en la época precolombina y termina con el fin de la guerra civil. El segundo comienza con la reconstrucción y cierra con la primera administración de Reagan. Cada capítulo -30 en total- contiene además de un relato breve, un tanto esquemático, un esbozo biográfico sobre una personalidad conocida o desconocida, un ensayo sobre un tópico representativo de la época, y una bibliografía selecta actualizada.

Esta segunda edición -la original es de 1979- impecable en su for- 
mato, enriquecida gráficamente por mapas, ilustraciones y totografías, se ha aumentado con 24 nuevos esbozos biográficos y otros han sido ampliados. También fueron añadidos varios nuevos ensayos sobre temas particulares.

GZP

BBF

973

ZIN

124. Zinn, Howard, A people's history of the United States, Nueva York, Harper Colophon Books, 1980, 614 p.

Producto de 20 años de enseñanza e investigación, el autor nos presenta una obra crítica y sugestiva de los grandes momentos de la historia norteamericana, desde el descubrimiento de América hasta las crisis más recientes de la guerra de Vietnam y de la caída de Nixon. Aparte de su estilo narrativo brillante, en el que las citas se ajustan perfectamente al desarrollo del texto, la novedad de este trabajo radica en su punto de partida fundamental: se trata de "la otra historia" escrita desde la perspectiva de las clases subalternas, sin caer en el maniqueísmo de las historias tradicionales. Al final se incluye bibliografía actualizada para cada uno de los 21 capítulos que conforman la obra. Contiene además un índice temático-onomástico.

COLMEX 125. Link, Arthur S. et al., The American people: a history, 973 Arlington Heights, Ill., A.H. M. Publishing Corporation, A512 1981, 1040 p.

Los historiadores responsables dedican esta obra a los jóvenes que pronto tendrán en sus manos el destino de los Estados Unidos. Piensan que sólo en la medida en que conozcan su historia y adquieran conciencia de que como nación han sido culpables de "genocidio, esclavitud, discriminación racial y sexual, agresión, persecución...", etc. (p. v), podrán enfrentar los problemas del presente y del futuro. Proporcionan además otras razones para estudiar su pasado: los Estados Unidos no sólo contribuyeron, con su Declaración de Independencia a la libertad humana, sino que a lo largo de su desarrollo histórico han demostrado que se puede cambiar sin necesidad de usar métodos violentos o totalitarios (la excepción es la guerra civil, al parecer necesaria para unificarlos) y que diversas razas, religiones y culturas pueden convivir pacíficamente y fortalecer así a la nación.

El libro se extiende desde, los primeros contactos entre las culturas europeas y americanas hasta las elecciones presidenciales de 1980. Hace énfasis en las contribuciones del pueblo norteamericano a la historia social y cultural, sin por ello dejar de lado la historia política. Al terminar cada capítulo propone una selección bibliográfica que menciona tanto los títulos más tradicionales de la historiografía como las más recientes aportaciones, en especial en los campos de la economía, la mujer, la familia, la demografía, el trabajo, etc. Al final cuenta con un apéndice documental y un índice onomástico.

Merecen mención especial las ocho secciones de ilustraciones de la obra, dedicada cada una a un aspecto diferente de la historia estadunidense. Destaca en especial la que versa sobre la experiencia mexicanoestadunidense. 
COLMEX 126. Norton, Mary et al., A people \& a nation. A history of

973

P419

the United States, Boston, Houghton Mifflin, 1982, $984 \mathrm{p}$.

Preocupados por el papel histórico de "Los de abajo", los autores no ven la historia de los Estados Unidos como continuidad y consenso. Piensan que, por el contrario, aunque a veces ha sido triunfante, tiene mucho de perturbadora.

El libro, que cubre desde las exploraciones europeas en América hasta el triunfo de Ronald Reagan en 1980, se basa tanto en investigaciones reconocidas como en estudios recientes. Trata aspectos tradicionales - politica externa e interna, patrones económicos, historia militar-, pero con nuevos enfoques. Presta atención, por ejemplo, a lo que los norteamericanos esperan de sus gobiernos, a la forma en que ejercen el poder, a los orígenes domésticos de su política exterior, etc. En cuanto a lo económico y social, la obra destaca el desarrollo tecnológico y sus efectos sobre los trabajadores; muestra interés en las causas de la movilidad geográfica de la población dentro del país y en la forma en que se adapta a sus nuevos ambientes; estudia la interacción entre las diversas razas y etnias, las divisiones sociales resultantes y los esfuerzos hechos para remediarlas; no olvida los diferentes aspectos de la vida diaria: religión, educación y trabajo, dieta y vestido, familia y diversiones.

Deseosos de que sus lectores reflexionen sobre la historia $-y$ no la memoricen -, los autores la narran en un lenguaje claro y concreto y la completan con mapas, ilustraciones, cuadros, gráficas, fotografías, documentos, perfiles estadísticos y un índice onomástico. 